Review

\title{
On the Chemistry, Toxicology and Genetics of the Cyanobacterial Toxins, Microcystin, Nodularin, Saxitoxin and Cylindrospermopsin
}

\section{Leanne Pearson ${ }^{1}$, Troco Mihali ${ }^{1}$, Michelle Moffitt ${ }^{2}$, Ralf Kellmann ${ }^{3}$ and Brett Neilan ${ }^{1, *}$}

1 School of Biotechnology and Biomolecular Sciences, The University of New South Wales, Sydney, NSW, 2052, Australia; E-Mails: leanne.pearson@unsw.edu.au (L.P.); troco@unsw.edu.au (T.M.)

2 School of Biomedical and Health Sciences, The University of Western Sydney, Campbelltown, NSW, 2560, Australia; E-Mail: M.Moffitt@uws.edu.au (M.M.)

3 Department of Molecular Biology, The University of Bergen, P.O. Box 7803, 5020 Bergen, Norway; E-Mail: Ralf.Kellmann@mbi.uib.no (R.K.)

* Author to whom correspondence should be addressed; E-Mail: b.neilan@unsw.edu.au; Tel.: +61-2-9385-3235; Fax: +61-2-9385-1483.

Received: 26 March 2010; in revised form: 2 May 2010 / Accepted: 6 May 2010 / Published: 10 May 2010

\begin{abstract}
The cyanobacteria or "blue-green algae", as they are commonly termed, comprise a diverse group of oxygenic photosynthetic bacteria that inhabit a wide range of aquatic and terrestrial environments, and display incredible morphological diversity. Many aquatic, bloom-forming species of cyanobacteria are capable of producing biologically active secondary metabolites, which are highly toxic to humans and other animals. From a toxicological viewpoint, the cyanotoxins span four major classes: the neurotoxins, hepatotoxins, cytotoxins, and dermatoxins (irritant toxins). However, structurally they are quite diverse. Over the past decade, the biosynthesis pathways of the four major cyanotoxins: microcystin, nodularin, saxitoxin and cylindrospermopsin, have been genetically and biochemically elucidated. This review provides an overview of these biosynthesis pathways and additionally summarizes the chemistry and toxicology of these remarkable secondary metabolites.
\end{abstract}

Keywords: cyanotoxin; non-ribosomal peptide; polyketide; alkaloid; toxicology 


\section{Microcystin}

\subsection{Introduction}

The heptapeptide hepatotoxin, microcystin, has been isolated from multiple genera of cyanobacteria, including Microcystis, Anabaena, Oscillatoria, Planktothrix, Chroococcus and Nostoc. Microcystin-producing strains such as Microcystis aeruginosa have a cosmopolitan distribution and thrive in a range of climates, making these organisms a global threat to human health. Consequently, significant research efforts have been directed towards their identification and eradication.

\subsection{Chemistry}

The microcystins comprise the largest and most structurally diverse group of cyanobacterial toxins. Around 90 microcystin isoforms varying by degree of methylation, hydroxylation, epimerization, peptide sequence and toxicity have been identified [1,2]. Underlying the extraordinary heterogeneity present among the microcystins is their common cyclic structure (Figure 1) and possession of several rare, highly conserved amino acid moieties. Collectively, the microcystins may be described as monocyclic heptapeptides containing both D- and L-amino acids plus $N$-methyldehydroalanine and a unique B-amino acid side-group, 3-amino-9-methoxy-2-6,8-trymethyl-10-phenyldeca-4,6-dienoic acid (Adda) [3]. The microcystin isoforms differ primarily at the two L-amino acids, and secondarily on the presence or absence of the methyl groups on D-erythro- $\beta$-methylaspartic acid (D-MeAsp) and/or $N$-methyldehydroalanine (Mdha) [4]. However, substitutions of all moieties within microcystin have been reported [5-7].

Figure 1. Structure of microcystin. General numbering of residues is indicated. Microcystin is a cyclic heptapeptide. The two variable amino acids in microcystin are indicated by $\mathrm{X}$ and $\mathrm{Y}$. The most common isoform is microcystin-LR (MW 995.17), where $\mathrm{X}$ is L-Leu and $\mathrm{Y}$ is L-Arg.

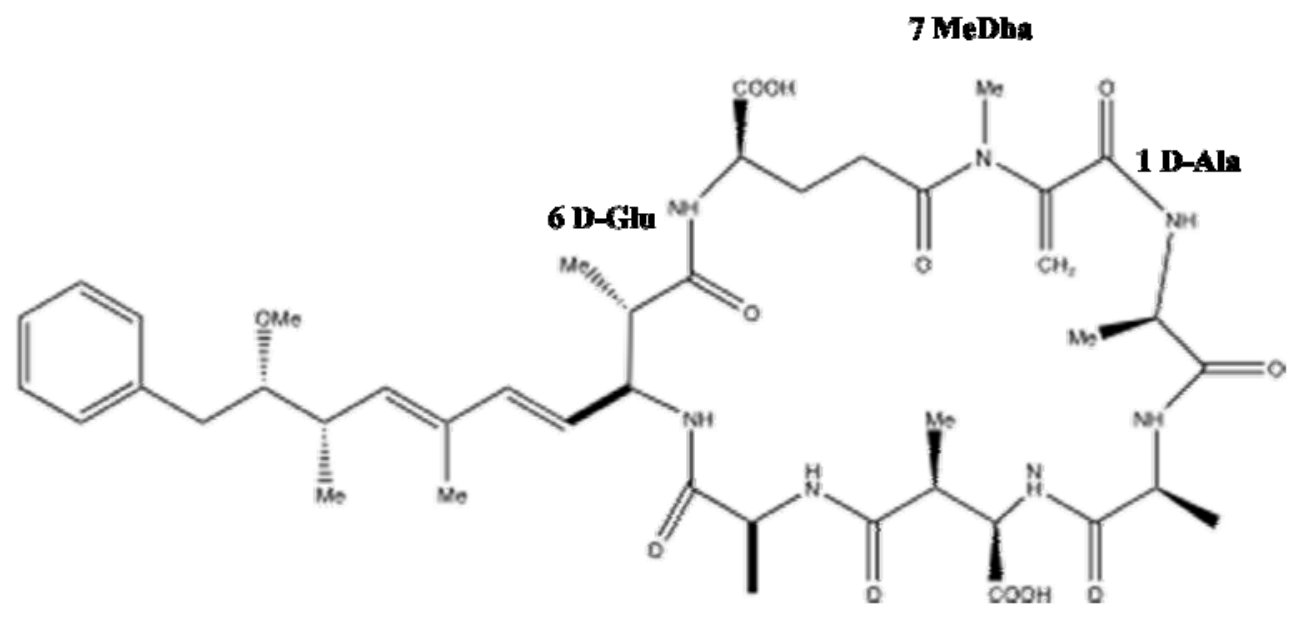

5 Adda

$4 \mathbf{Y}$ 


\subsection{Toxicology}

Acute cases of microcystin poisoning may cause rapid death in humans and other animals [8]. Upon ingestion, microcystin is transported to the liver by organic anion transport proteins where they exert their toxicity via inhibition of protein phosphatases 1 and $2 \mathrm{~A}$ [9-11]. Inhibition of protein phosphatases can lead to excessive phosphorylation of structural filaments, subsequent cyto-skeletal degradation and breakdown of hepatic ultra structure [12,13]. Retraction of hepatocytes from neighboring cells and sinusoidal capillaries causes blood to become pooled in the liver tissues. This ultimately results in local tissue damage, organ failure and haemorrhagic shock [13].

Varying levels of toxicity have been reported for each microcystin isoform. For example, the LD50 of the most common isoform, microcystin-LR, is $50 \mu \mathrm{g}$ per kilogram of body weight in mice [14], while the rarer microcystin-RR requires a significantly higher dose of $600 \mu \mathrm{g}$ to produce the same lethal effect [15].

The revelation that cyanobacterial hepatotoxins cause protein phosphatase inhibition has raised the disturbing possibility that human exposure to non-lethal doses of these compounds may contribute to the development of cancer [16,17]. Several laboratory studies have indicated that chronic exposure to microcystin can indeed promote skin and liver tumors in rats and mice [18,19]. Epidemiological data suggest that similar long-term effects such as hepatocellular carcinoma may also be observed in humans [20,21]. Such results highlight the need for sensitive and rapid detection methods and stringent monitoring of cyanobacterial hepatotoxins in drinking water supplies.

\subsection{Biosynthesis and Genetics}

Microcystin is synthesized non-ribosomally by the thiotemplate function of a large multifunctional enzyme complex containing both non-ribosomal peptide synthetase (NRPS) and polyketide synthase (PKS) domains. The gene cluster encoding these biosynthetic enzymes, mcyS, has been sequenced and partially characterized in several cyanobacterial species including Microcystis, Anabaena, and Planktothrix [22-24] (Figure 2). Such fundamental studies have offered insight into the evolution of cyanotoxin biosynthesis, and have additionally provided much of the groundwork for current PCR-based cyanobacterial detection methods.

The microcystin biosynthesis gene cluster, mcyS, was the first complex metabolite gene cluster to be fully sequenced from a cyanobacterium. In M. aeruginosa PCC7806, the mcyS gene cluster spans $55 \mathrm{~kb}$ and comprises 10 genes arranged in two divergently transcribed operons, mcyA-C and mcyD-J. The larger of the two operons, mcyD-J, encodes a modular PKS (McyD), two hybrid enzymes comprising NRPS and PKS modules (McyE and McyG), and enzymes putatively involved in the tailoring (McyJ, F, and I) and transport (McyH) of the toxin. The smaller operon, mcyA-C encodes three NRPSs (McyA-C) [22].

The formation of Adda putatively involves enzymes encoded by mcyD-G and $J$, based on bioinformatic analyses and homology to related enzymes (Figure 3a). The hybrid NRPS/PKS enzyme, McyG, constitutes the first step in Adda biosynthesis. It was initially hypothesized that the NRPS module of McyG activates phenylacetate, however, recent biochemical characterization of the McyG A-PCP didomain has revealed that assorted phenylpropanoids are preferentially activated and loaded 
onto the PCP [25]. Following activation, the phenylpropanoid starter unit is extended by several malonyl-CoA elongation steps and subsequently modified by $C$-methylation, reduction and dehydration, all catalyzed by the PKS modules of McyD, E and G. The aminotransferase domain of McyE then converts the polyketide to a $\beta$-amino acid in the final step of Adda biosynthesis. The NRPS module of the second hybrid PKS/NRPS enzyme, McyE, is thought to be involved in the activation and condensation of D-Glu with Adda.

Figure 2. Hepatotoxin gene clusters from various cyanobacteria. Structures of the microcystin and nodularin gene clusters of (A) N. spumigena, (B) M. aeruginosa, (C) P. agardhii, and (D) Anabaena sp. 90, showing genes encoding polyketide synthases (white), non-ribosomal peptide synthetases (red), tailoring enzymes (grey), and ABC-transporters (black). Diagram not drawn to scale.

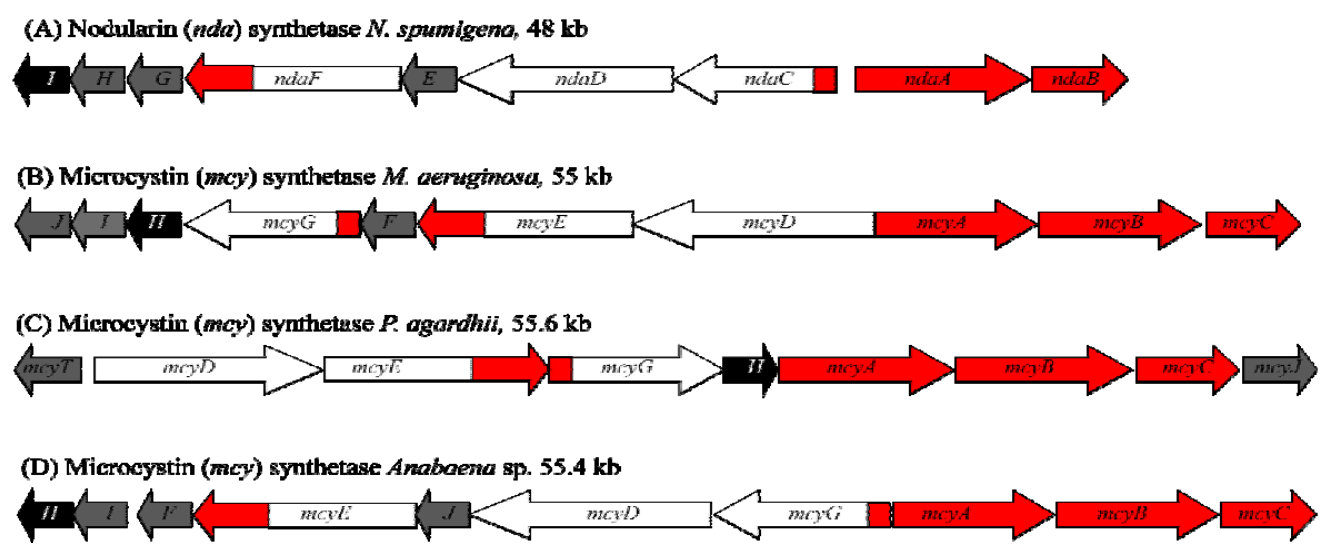

The mcyF ORF was originally predicted to encode a glutamate racemase, responsible for the epimerization of the L-Glu residue of microcystin [22,26]. A subsequent study by [27] contended this theory and offers evidence that McyF acts exclusively as an Asp racemase. The authors propose that the D-Glu residue is provided by an L-Glu racemase residing outside the mcyS gene cluster. Mutagenesis experiments in $P$. agardhii showed that the production of Adda also involves an $O$-methylation step catalyzed by the putative monofunctional tailoring enzyme, McyJ [23].

The remaining biosynthetic enzymes in the microcystin biosynthesis pathway (NRPSs) are putatively involved in the specific activation, modification and condensation of substrate amino acids onto the linear peptide chain, which is then cyclized to produce microcystin. Firstly, McyA adds L-Ser to the growing chain, followed by the addition of D-Ala. This step is followed by the addition of L-Leu and D-MeAsp residues (McyB) followed by the addition of L-Arg (McyC), and subsequent cyclization and release of the final peptide product (Figure $3 \mathrm{~b}$ ).

The remaining stand alone enzyme, the 2-hydroxy-acid dehydrogenase, McyI, is putatively involved in the production of D-methylaspartate at position three within the microcystin cyclic structure via the conversion of 3-methylmalate to 3-methyloxalacetate. It is hypothesized that a promiscuous aspartate aminotransferase then converts 3-methyloxalacetate to methylaspartate [28].

$\mathrm{An} \mathrm{ABC}$ transporter gene, $m с y H$, is believed to be involved in the transport of microcystin [29]. This transporter may be responsible for the thylakoid localization of the toxin [30,31] or for the extrusion of the toxin under certain growth conditions, including exposure to high and red light [32]. 
Figure 3. (uper) Model for the formation of Adda during microcystin biosynthesis and predicted domain structure of McyG, McyD and McyE. (lower) Biosynthetic model for microcystin-LR and predicted domain structure of McyE, McyA, McyB, and McyC. Each circle and rectangle represents, respectively, a PKS or NRPS enzymatic domain. The aminotransferase domain is represented by a diamond. The activity of the tailoring ORFs, McyJ, F and I, are shown as inverted triangles. Abbreviations are as follows: A, aminoacyl adenylation; ACP, acyl carrier protein; AMT, aminotransferase; AT, acyltransferase; C, condensation; CM, C-methyltransferase; DH, dehydratase; Ep, epimerization; KR, ketoacyl reductase; KS, $\beta$-ketoacyl synthase; NM, $N$-methyltransferase; $\mathrm{OM}, \mathrm{O}$-methyltransferase; RC, racemase; TE, thioesterase. The NRPS thiolation motif is shown in black (reproduced from [22]).
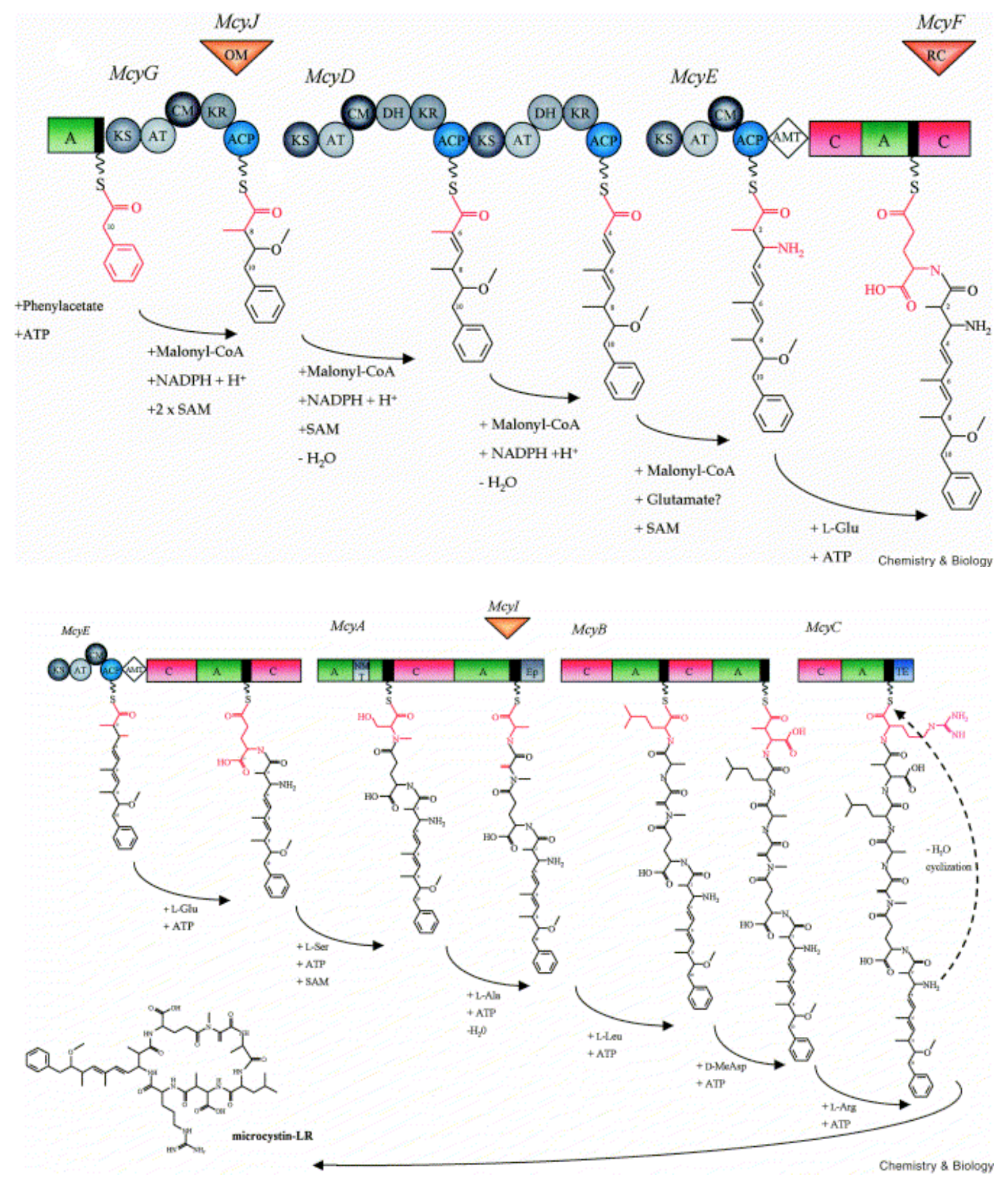
Comparative studies of the mcyS gene clusters from M. aeruginosa, P. agardhii [23], and Anabaena sp. [24] have noted variation in the arrangement of mcyS genes between these different species of cyanobacteria, although the proposed toxin biosynthetic processes are thought to be similar. The M. aeruginosa and Anabaena sp. mcyS clusters are both arranged into two divergently transcribed operons, however, the arrangement of genes within these operons differs between the two species (Figure 2). In P. agardhii, the mcyS cluster also has a distinctive arrangement and lacks mcyF and mcyI. Furthermore, the $P$. agardhii mcyS cluster contains an additional gene mcyT, upstream of the central promoter region. This gene is thought to encode a putative type II thioesterase enzyme, which may play an editing role by removing mis-primed amino acids from the NRPS and PKS enzymes. The characterization of mcyS in $M$. aeruginosa, P. agardhii and Anabaena sp. has important implications for understanding the origins and evolution of hepatotoxin biosynthesis in cyanobacteria. The identification of transposases associated with the mcyS and ndaS (nodularin) gene clusters and subsequent phylogenetic analysis has led to the theory that horizontal gene transfer and recombination events are responsible for the sporadic distribution of the mcyS gene cluster throughout the cyanobacteria and the various microcystin isoforms that have been identified to date [22,33,34].

Hepatotoxin production in cyanobacteria is thought to be influenced by a number of different physical and environmental parameters, including nitrogen, phosphorous, trace metals, growth temperature, light, and $\mathrm{pH}$ [35-41]. However, due to the fact that most regulatory investigations have not been standardized, and the data have not been interpreted against the same specific growth controls, the subject of hepatotoxin regulation remains a somewhat contentious issue. While most toxin regulation studies have focused on direct measurements of cellular toxin, the description of the mcy gene cluster by Tillett and co-workers [22] enabled a closer examination of microcystin regulation at the molecular level [32]. Kaebernick et al. used the RNase protection assay to measure the transcription of $m c y B$ and $m c y D$ under a variety of different light conditions. High light intensities and red light were correlated with increased transcription, while blue light led to reduced transcript levels. Interestingly, the authors observed two light thresholds, between dark and low light $(0$ and $16 \mu \mathrm{mol}$ photons $\left.\mathrm{m}^{-2} \mathrm{~s}^{-1}\right)$, and medium and high light $\left(31\right.$ and $68 \mu \mathrm{mol}$ photons $\left.\mathrm{m}^{-2} \mathrm{~s}^{-1}\right)$, at which a significant increase in transcription occurred. The same group later found that transcription of mcy genes occurs via two polycistronic operons, mcyABC and mcyDEFGHIJ, from a central bidirectional promoter between mcyA and mcyD [42]. Interestingly, alternate transcriptional start sites were identified for both operons when cells were cultured under different light intensities. For example, under low light conditions, the polyketide and tailoring genes $m c y D-J$ are transcribed as part of a polycistronic message (mcyDEFGHIJ) from a central $(m c y D)$ promoter, while under high light conditions, the genes are transcribed from an alternative up-stream promoter. It is thought that initiation from the alternate promoters under high light conditions may lead to increased transcription, as previously observed for $m c y B$ and $m c y D$. Many of the tailoring enzymes (mcyF, G, H, I and $J$ ) also possess their own individual promoters [32].

Interestingly, light intensity also appears to favor the production of certain microcystin variants over others. For example, Tonk et al. (2005) found that the cellular content of total microcystin remained constant, independent of the irradiance. However, of the two main microcystin variants detected in P. agardhii, the microcystin-DeRR content decreased two-fold with increased photon irradiance, whereas the microcystin-DeLR content increased three-fold. Since microcystin-DeLR is 
considerably more toxic than microcystin-DeRR, this implies that $P$. agardhii becomes more toxic at high light intensities [40].

Other factors such as nutrient content and temperature have also been demonstrated to affect mcyS expression and toxin biosynthesis. For example, Sevilla et al. (2008) investigated the effect of iron on mcyS expression and toxin biosynthesis in M. aeruginosa PCC7806 [41]. Real-time PCR analysis and HPLC were used to measure transcription of mcyD and the synthesis of microcystin-LR, respectively. The results of this study suggested that iron starvation causes an increase in mcyD transcription, correlative to the increase of toxin levels [41]. Davis et al. (2009) investigated the effects of temperature on Microcystis growth and toxin genes and found that elevated temperatures yield more toxic Microcystis cells and/or cells with more mcyD copies per cell, with either scenario potentially yielding more toxic blooms [39].

\section{Nodularin}

\subsection{Introduction}

The cyclic pentapeptide nodularin is most commonly isolated from the filamentous, planktonic cyanobacterium, Nodularia spumigena. This species generally forms toxic blooms in brackish and estuarine environments. Blooms of toxic N. spumigena occur annually during summer months in the Baltic Sea [43] resulting in nodularin being one of the most abundant naturally occurring compounds in the Baltic Sea. Blooms are also particularly common within the estuaries and coastal lagoons of Australia [44,45], and have been reported worldwide, including on the German North Sea coast [46], New Zealand [47], and North America [48]. N. spumigena scums have also been reported in the fresh to brackish/saline lakes at the mouth of the lower River Murray, South Australia, which is a major source of both potable and irrigation water [49]. Nodularin is structurally similar to microcystin and can induce similar toxic effects. The toxin has been reported to have detrimental effects on numerous organisms within the ecosystem, including invertebrates and fish, but may have no effect on other organisms [50].

The consumption of water containing toxic $N$. spumigena blooms has led to the death of domestic and native animals by massive liver haemorrhage [46,47,51,52]. In sub-acute doses, nodularin, like microcystin, is thought to act as a liver tumor initiator and promoter [53]. N. spumigena blooms are also of importance to the seafood industry. Nodularin has been shown to accumulate in shellfish and other seafood. Surveys of mussels, prawns, flounder both in Australia and the Baltic Sea report that nodularin accumulated to levels of concern with the potential to cause hepatotoxicity [54-56].

\subsection{Chemistry}

Nodularin is a cyclic pentapeptide with a similar structure to microcystin, consisting of Adda, D-glutamic acid (D-Glu), $N$-methyldehydrobutyrine (MeDhb), D-erythro- $\beta$-methylaspartic acid (D-MeAsp), and L-arginine (L-Arg) (Figure 4) [57].

Seven naturally-occurring isoforms of nodularin have been reported to date. Two of these isoforms, produced by a New Zealand Nodularia sp. bloom, have variations within the Adda residue, which reduces or abolishes the toxicity of the compound [5]. The D-Glu residue is essential for toxicity of 
nodularin, as esterification of its free carboxyl abolishes toxicity, however, substitution at position 1 has little effect on toxicity. The other two isoforms, nodularin-Har and motuporin, are variable at position 2. Nodularin-Har is produced by the strain N. harveyana PCC7804, with the L-Arg, replaced with L-Homoarginine (L-Har) [58,59]. Motuporin has been isolated from the Papua New Guinea sponge Theonella swinhoei, and may be synthesized by an associated cyanobacterium. The L-Arg residue of nodularin is replaced by L-Val in motuporin [60]. The L-Val residue is responsible for additional cytotoxicity of motuporin against cancer cell lines.

Figure 4. Structure of nodularin. General numbering of residues is indicated. Nodularin is a cyclic pentapeptide (MW 619). The L-Arg residue of nodularin may be replaced with a homoarginine (nodularin-Har) or valine residue (motuporin).

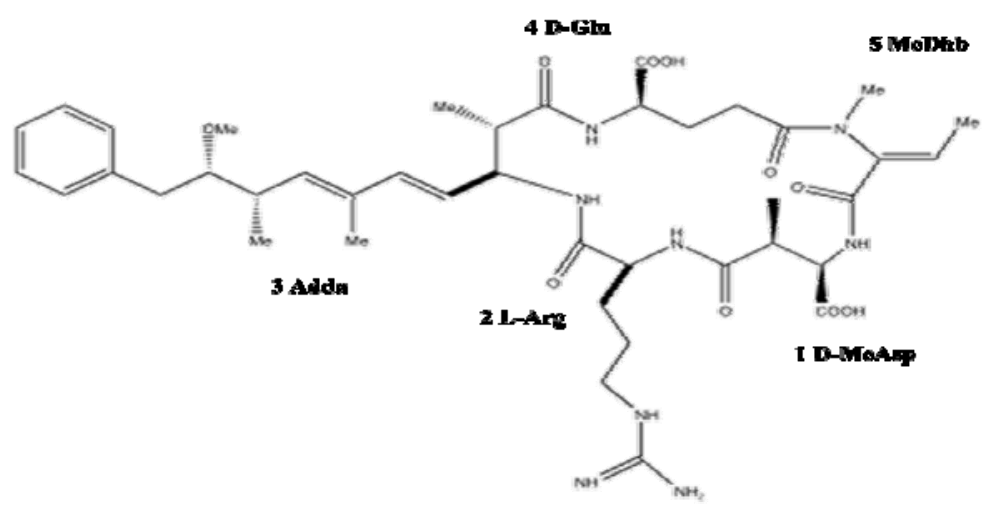

\subsection{Toxicology}

Nodularin is a potent hepatotoxin in humans and other animals. Nodularin induces liver hemorrhage in mice and has a lethal dose $50\left(\mathrm{LD}_{50}\right)$ of $50 \mu \mathrm{g} \cdot \mathrm{kg}^{-1}$ (intra-peritoneal route of injection) in mice [61]. At doses below this concentration, nodularin may act as a carcinogen via the initiation and promotion of liver cell division [53].

The hepatotoxicity and carcinogenicity of nodularin is associated with the inhibition of eukaryotic protein phosphatase (PP) catalytic subunit types 1 and 2A [62]. The toxin inhibits the activity of PP2A to a greater extent than PP1. Inhibition of PP2A by nodularin occurs at relatively the same concentration $\left(\mathrm{IC}_{50}\right)$ as that of microcystin $(\sim 0.1 \mathrm{nM})$ [62]. The hydrophobic $\mathrm{C}_{20} \beta$ - amino acids Adda, present in both toxins, blocks PP enzyme activity by interacting with the hydrophobic groove and obstructing substrate access to the active site cleft [63-65]. MeDhb binds to Cys273 of PP2A in a similar fashion to the MeDha residue in microcystin which binds to Cys273 of PP1 and Cys266 of PP2A $[64,66]$, however, binding of the toxin does not occur covalently and may be the reason for its additional carcinogenic properties [67].

The toxic effects of nodularin are primarily associated with the hepatocytes due to active transport of the toxin to the liver via the bile acid multi-specific organic anion transporters [10]. To date, studies have been unable to identify the specific mechanism of transport.

Nodularin has been observed to accumulate on different trophic levels, in numerous organisms including waterfowl, fish, mysid shrimp, zooplankton and benthic organisms [68]. Mesozooplankton in particular seem to play a major role in nodularin transfer to planktivorous fish [68]. The toxin 
appears to cause oxidative stress in the tissues in which it accumulates. In the case of the flounder (platichthys flesus L.), this oxidative stress occurs in the liver by way of reduced GST and CAT activities [69]. However, recent studies suggest that the toxin is rapidly detoxified and broken down or excreted [70].

\subsection{Biosynthesis and Genetics}

The nodularin biosynthesis gene cluster ndaS, from Nodularia spumigena NSOR10, was sequenced and characterized in 2004 by Moffitt and Neilan [71]. The $48 \mathrm{~kb}$ region of the genome consists of nine ORFs (ndaA-I) transcribed from a bidirectional regulatory promoter region (Figure 2). While most of the ndaS encoded genes have homologs in the mcyS cluster, their arrangement adheres more closely to the 'co-linearity' rule of NRPS pathways that predicts the order of catalytic processes involved in the biosynthesis of a non-ribosomal metabolite is generally the same as the order of the genes which encode their catalytic enzymes [72].

The proposed pathway for nodularin biosynthesis is similar to that for microcystin. Functional assignment of the enzymes was based on bioinformatic analysis and homology to the microcystin synthetase enzymes. The Adda side-chain is produced via a mixed NRPS/PKS pathway from a phenylacetate starter unit and several malonyl-CoA extensions (NdaC, D and F) (Figure 5). The NRPS module of the hybrid NRPS/PKS, NdaF, subsequently adds D-Glu to the growing chain. Two NRPS enzymes, NdaA and B, complete the cyclic pentapeptide by adding the final amino acid residues, L-Thr, D-MeAsp and L-Arg. The NRPS modules responsible for the activation of D-Ala and D-Leu in mcyS (McyA and B) are absent from ndaS as nodularin lacks these moieties. The NRPS and PKS proteins require posttranslational modification by a phosphopantetheinyl transferase (PPT) protein. The PPT required for activation of the Nda proteins is not clustered with the other nda genes. Recently, degenerate PCR and subsequent functional enzymatic characterization, identified the PPT required for nodularin biosynthesis in N. spumigena NSOR10 [73].

The ndaS cluster also encodes several putative monofunctional tailoring enzymes that may play a role in the modification and transport of nodularin. ndaE encodes an $O$-methyltransferrase, ndaG encodes a putative L-Asp/L-Glu racemase, and ndaI encodes an ABC transporter. Also encoded within the ndaS cluster is a D-3-PGDH homolog, $\mathrm{NdaH}$, which shares $71 \%$ identity with McyI. It is likely therefore, that NdaH may be involved in the production of D-MeAsp [28].

Like mcyS, the ndaS gene cluster is transcriptionally regulated by a bi-directional promoter region. Analysis of transcription of the ndaS cluster found that it is transcribed as two polycistronic mRNA, ndaAB, ORF1, and ORF2, and ndaC [71]. The two genes downstream of ndaAB, ORF1 and ORF2, encode a putative transposase and a putative high light-inducible chlorophyll-binding protein, respectively. It is not clear why the putative transposase and the putative high light-inducible chlorophyll-binding protein are also co-transcribed with the ndaS gene cluster. ORF2 has been identified in all strains of toxic Nodularia and the association between ORF2 and nodularin biosynthesis may suggest a physiological function associated with high-light stress in the cells producing it. A putative heat shock repressor protein, encoded by the gene ORF3, was also identified downstream of ORF2, which may be involved in the transcriptional regulation of the ndaS genes in response to heat stress. 
Figure 5. (uper). Model of the formation of Adda during nodularin biosynthesis and predicted domain structure of $\mathrm{NdaC}, \mathrm{D}$ and $\mathrm{F}$. (lower). Biosynthetic model for nodularin and predicted domain structure of NdaF, H, A and B. Each grey and green circle represents, respectively, a PKS or NRPS enzymatic domain. The activities of the tailoring ORFs, NdaE, $\mathrm{G}$ and $\mathrm{H}$, are shown as inverted triangles. Abbreviations are as follows: A, aminoacyl adenylation; ACP, acyl carrier protein; AMT, aminotransferase; AT, acyltransferase; C, condensation; CM, C-methyltransferase; DH, dehydratase; Ep, epimerization; KR, ketoacyl reductase; KS, $\beta$-ketoacyl synthase; NM, $N$-methyltransferase; OM, O-methyltransferase; RC, racemase; TE, thioesterase. (reproduced from [71]).
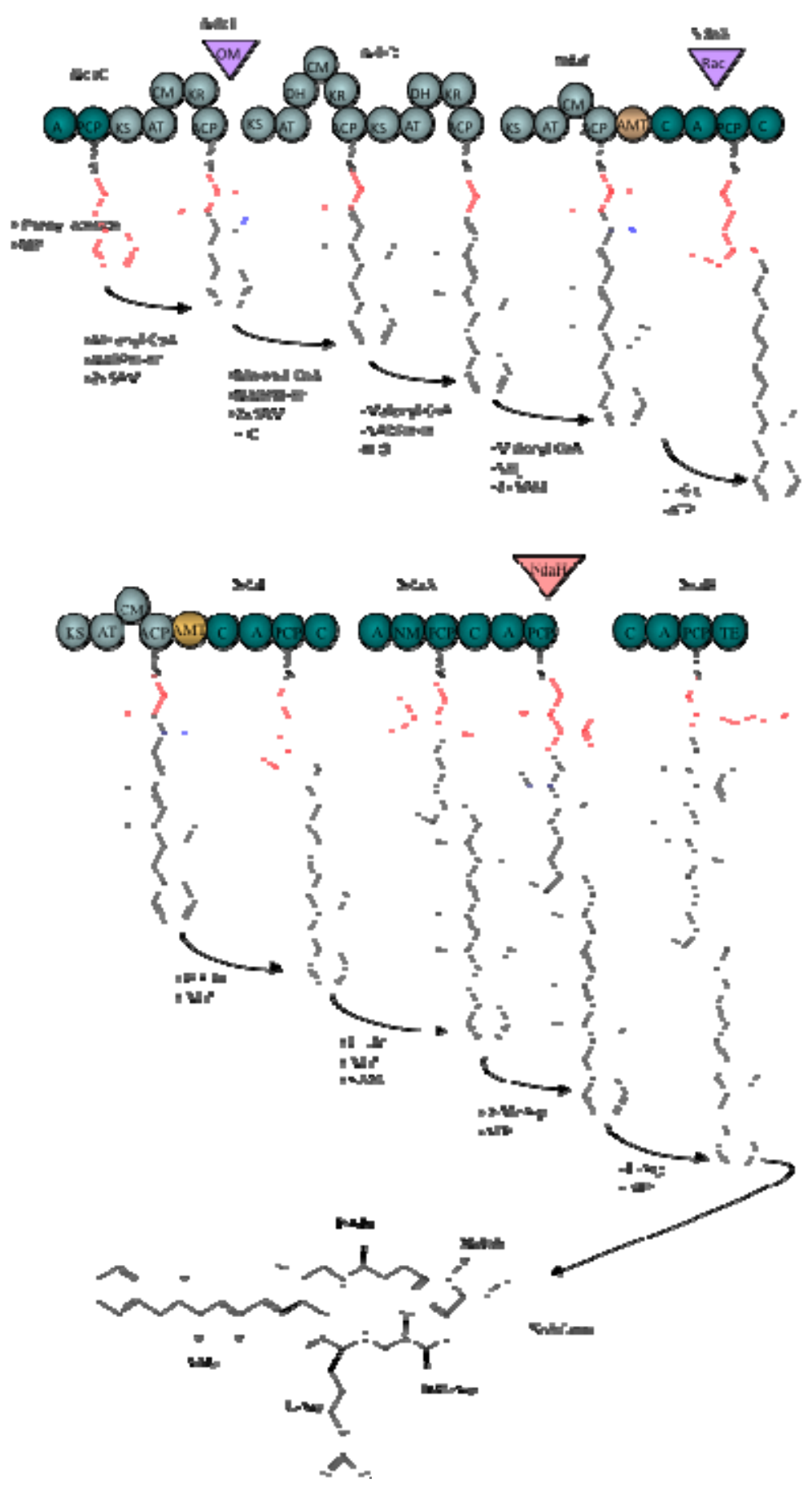
More recently, elucidation of the nda cluster has provided an opportunity to monitor transcriptional regulation of the biosynthetic pathway [74]. The effects of ammonia and phosphate starvation were analyzed. While expression of the nda cluster appears to be constitutive, phosphate starvation resulted in an approximately two-fold increase in expression, while ammonia supplementation decreased expression two-fold. Despite the changes to expression, intracellular and extracellular nodularin concentration remained stable [74].

\section{Saxitoxin}

\subsection{Introduction}

Saxitoxin and its analogs, collectively termed paralytic shellfish poisons (PSPs), are highly potent neurotoxins. Several freshwater species of cyanobacteria and marine dinoflagellates are known to produce saxitoxins. Blooms of these toxic species have led to mass kills of fish, native animals and livestock, as well as the contamination of freshwater resources [75-77]. Saxitoxins typically accumulate through the food chain, in organisms consumed as seafood [78]. Marine shellfish are particularly resistant to the toxins, and can therefore accumulate dangerously high levels of PSPs by ingesting toxic plankton [79]. Saxitoxin and its analogs cause an annual estimated 2000 cases of PSP globally, with a mortality rate of $15 \%$ [80].

The capacity to synthesize saxitoxins and other PSPs has an unusually wide phylogenetic distribution, including both marine and freshwater organisms from two kingdoms of life (Eubacteria and Protista). Typically, there is little convergence between the structures of secondary metabolites from marine and freshwater organisms [81], or from organisms belonging to different phylogenetic groups. Although several studies suggest that other bacteria are capable of synthesizing PSPs [82,83], the findings are controversial, as the analytical methods used were not definitive and could not be readily repeated by other researchers [84]. On the other hand, PSP biosynthesis in cyanobacteria and dinoflagellates has been extensively verified and shown to be a consistent and heritable genetic trait [85-90].

In the marine environment, dinoflagellate species capable of producing saxitoxins belong to the genera Alexandrium, Pyrodinium and Gymnodinium [91-93]. While in freshwater systems, several filamentous species of cyanobacteria, such as Anabaena circinalis, Aphanizomenon sp., Aphanizomenon gracile, Cylindrospermopsis raciborskii and Lyngbya wollei are also known to produce saxitoxins [94-97]. Saxitoxin production is varied among dinoflagellate and cyanobacterial producer genera, with not all species in a toxigenic genera being toxic, and different isolates of the same species having differential toxicity. Furthermore, cyanobacterial isolates of the same species from geographically distant locations provided different toxin profiles [89].

\subsection{Chemistry}

Saxitoxin is a trialkyl tetrahydropurine and the parent compound of more than 30 naturally occurring derivatives that differ structurally at four positions [98] (Figure 6.). The variable positions may be hydroxylated, sulfated or carbamoylated. Most of these analogs have been detected in both cyanobacteria and dinoflagellates [95,96,98-101]. In addition to the usual carbamate and decarbamoyl 
toxins, six new saxitoxin derivatives have been isolated from the cyanobacteria Lyngbya wollei, including derivatives which provided an acetyl side-chain instead of the typical carbamate, or lacked one of the C-12 hydroxyl moieties [102]. Further unusual modifications, such as a C-11 ethanoic acid side-chain [103], or the $N$-hydroxylation of the carbamoyl side-chain [104], have also been described in xanthid crabs. In addition, the freshwater puffer fish was shown to produce a unique saxitoxin analog where the carbamoyl side-chain is $N$-methylated [105]. Furthermore, the Panamanian golden frog Atelopus zeteki produces zetekitoxin AB, which was recently confirmed to be a novel analog of saxitoxin, with sodium channel blocking activity 580-fold higher than that of saxitoxin [106]. Whether or not these complex eukaryotic organisms actually produce PSPs or simply accumulate the toxins in their tissues and organs is an issue of contention.

Figure 6. The core chemical structure of the paralytic shellfish poison (PSP), saxitoxin. ' $R$ ' represents variable positions. For a detailed list of isoforms see [98].

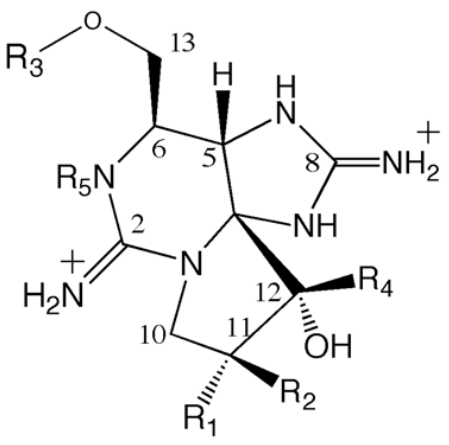

\subsection{Toxicology}

Saxitoxin and its derivatives are the causative agents of the common seafood poisoning, paralytic shellfish poisoning (PSP). PSP symptoms generally onset within 30 minutes of ingestion, and invariably begin with a tingling or burning of the lips, tongue and throat, increasing to total numbness of the face [98]. Further symptoms may include perspiration, vomiting and diarrhea. In cases of acute poisoning, numbness may spread to the neck and extremities and progress to muscular weakness, loss of motor coordination, and finally paralysis. A lethal dose of saxitoxin usually results in cardiovascular failure due to respiratory muscle paralysis [98]. There is no clinically approved antidote to saxitoxin poisoning, and treatments during early stages of PSP include removal of unabsorbed toxin with activated charcoal, and artificial respiration. The half-life of saxitoxin in the body is approximately 90 minutes, and survival chances increase significantly after 12 hours from initial exposure [107]. It is a highly potent blocker of voltage gated sodium channels present in neuronal cell membranes [108]. In addition, saxitoxin has also been shown to block calcium channels [109], and to prolong the gating of potassium channels in heart muscle cells [110]. Saxitoxin is a highly potent phycotoxin with an intraperitoneal $\mathrm{LD}_{50}$ of $10 \mu \mathrm{g} / \mathrm{kg}$ body weight in mice [111], while human death has occurred following the ingestion of as little as $1 \mathrm{mg}$ of the toxin [112].

Mammals usually contain multiple isoforms of sodium channels, with different sensitivity to saxitoxin. This difference in sensitivity is due to variation in the amino acid sequence of the channel alpha subunit, whereby a single mutation may confer insensitivity to saxitoxin, though usually 
sacrificing speed of gating in the process [113]. The guanidinium groups and the carbon 12 hydroxyls in STX have been shown to be critical for the binding of the sodium channel, while the carbamoyl side chain also appears to be involved in the binding process, whereby one saxitoxin molecule binds one channel by lodging itself in the ion-conducting pore [113-116].

The toxicity of saxitoxin derivatives varies greatly, with the carbamate toxins being 10-100-times more potent than the $N$-sulfo-carbamoyl derivatives [98,117]. $N$-sulfo-carbamoyl analogs are, however, labile and may easily be converted to the more toxic carbamate derivatives $[118,119]$.

\subsection{Biosynthesis and Genetics}

Using a reverse genetic approach, Kellmann and co-workers [120] identified the gene cluster putatively responsible for the biosynthesis of saxitoxin in Cylindrospermopsis raciborskii T3 (sxt) (Figure 7c). The sxt gene cluster is encoded by more than $35 \mathrm{~kb}$ and comparative sequence analysis assigns 30 catalytic functions to 26 proteins. Bioinformatic analysis of this cyanobacterial saxitoxin gene cluster, coupled with identification of novel biosynthetic intermediates enabled a revision of the previously proposed saxitoxin biosynthesis pathway (Figure 8).

The first step in the revised saxitoxin biosynthesis pathway involves a Claisen condensation reaction catalyzed by SxtA. This unique enzyme possesses a polyketide synthase (PKS)-like structure composed of four catalytic domains, SxtA1-4: SxtA1 is homologous to SAM-dependant methyltransferases; SxtA2 is related to GCN5-related $N$-acetyl transferases (GNAT) that transfer acetate from acetyl-CoA to various heteroatoms [121]; SxtA3 is related to ACPs and also provides a phosphopantetheinyl-attachment site; SxtA4 is homologous to class II aminotransferases and is most similar to AONS (8-amino-7-oxononanoate synthase). The predicted reaction sequence of SxtA, based on its primary structure, is the loading of the ACP (SxtA3) with acetate from acetyl-CoA, followed by the SxtA1-catalyzed methylation of acetyl-ACP, converting it to propionyl-ACP. SxtA4, the class II aminotransferase domain, then performs a Claisen condensation reaction between propionyl-ACP and arginine. The putative product of SxtA is thus 4-amino-3-oxo-guanidinoheptane, which Kellmann et al. designated compound A.

The sxtG gene encodes a putative amidinotransferase, with highest amino acid sequence similarity to L-arginine/L-lysine amidinotransferases. SxtA is the putative substrate for SxtG, which transfers an amidino group from arginine to the $\alpha$-amino $\mathrm{A}^{\prime}$ group, thus producing 4,7-diguanidino-3-oxoheptane (designated compound $\mathrm{B}^{\prime}$ ). SxtB, an enzyme similar to the cytidine deaminase-like enzymes from gammaproteobacteria, then catalyzes a retroaldol-like condensation in the conversion from $\mathrm{B}^{\prime}$ to $\mathrm{C}^{\prime}$.

The putative sterol desaturase, SxtD is predicted to introduce a double bond between C-1 and C-5 of $\mathrm{C}^{\prime}$, resulting in the 1,2-H shift between C-5 and C-6 (compound $\mathrm{D}^{\prime}$ ). The gene product of sxtS, which has sequence homology to nonheme iron 2-oxoglutarate-dependent dioxygenases, is predicted to perform the consecutive epoxidation of the new double bond and opening of the epoxide to an aldehyde with concomitant bicyclization. SxtU has sequence similarity to short-chain alcohol dehydrogenases and is therefore predicted to reduce the terminal aldehyde group of the saxitoxin precursor forming compound E'. The concerted action of SxtD, SxtS, and SxtU is therefore responsible for the hydroxylation and bicyclization of compound $\mathrm{C}^{\prime}$ to $\mathrm{E}^{\prime}$. 
The gene product of sxtI is most similar to a predicted $O$-carbamoyltransferase from Trichodesmium erythraeum and other cyanobacteria. Kellmann et al.'s data [120] indicate that SxtI may catalyze the transfer of a carbamoyl group from carbamoylphosphate to the free hydroxy group of $E^{\prime}$. Adjacent to sxtI are two short ORFs of unknown function, sxt $J$ and sxtK. While sxtJ and sxtK homologs are available in the databases, none of these genes have been functionally characterized.

sxtH and sxtT, each encode a terminal oxygenase subunit similar to those found in bacterial phenylpropionate and related ring-hydroxylating dioxygenases. SxtH and SxtT may therefore perform the consecutive hydroxylation of $\mathrm{C}-12$, converting $\mathrm{F}^{\prime}$ into saxitoxin. Members belonging to bacterial phenylpropionate and related ring-hydroxylating dioxygenases are multicomponent enzymes, as they require an oxygenase reductase for their regeneration after each catalytic cycle. The sxt gene cluster provides a putative electron transport system, which would fulfill this function in the form of SxtV and SxtW. SxtV, a 4Fe-4S ferredoxin, could putatively extract an electron pair from succinate, converting it to fumarate [122]. SxtW a fumarate/reductase/succinate dehydrogenase homolog could then transfer the electrons via ferredoxin to SxtH and SxtT.

Following synthesis of the parent molecule saxitoxin, modifying enzymes introduce various functional groups. In addition to saxitoxin, C. raciborskii T3 produces $N$-1-hydroxylated (neoSTX), decarbamoylated (dcSTX), and $N$-sulfurylated (GTX-5) toxins, whereas Anabaena circinalis AWQC131C produces decarbamoylated (dcSTX) toxins and $O$-sulfurylated (GTX-3/GTX-2, dcGTX$3 /$ dcGTX-2) toxins, as well as both $O$ - and $N$-sulfurylated toxins (C-1/C-2), but no $N$-1-hydroxylated toxins [99].

$s x t X$ encodes an enzyme with homology to cephalosporin hydroxylase. $s x t X$ was detected only in $C$. raciborskii T3, Aphanizomenon flos-aquae NH-5, and Lyngbya wollei, which produce $N$-1-hydroxylated analogs of saxitoxin [94,108,123], such as neoSTX. This component of the gene cluster was not present in any strain of $A$. circinalis, and therefore probably represents the reason why this species does not produce $N$-1-hydroxylated PSP toxins $[89,99]$. The predicted function of SxtX is therefore the $N-1$ hydroxylation of saxitoxin.

A. circinalis AWQC131C and C. raciborskii T3 also produce $N$ - and $O$-sulfated analogs of saxitoxin [GTX-5, C-2/C-3, (dc)GTX-3/GTX-4]. The activity of two 3'-phosphate 5'-phosphosulfate (PAPS)-dependent sulfotransferases, which were specific for the $N-21$ of saxitoxin and GTX-3/GTX-2 and the $O-22$ of 11-hydroxy saxitoxin, respectively, has been described previously in studies of the PSP toxin-producing dinoflagellate Gymnodinium catenatum [124,125]. A putative sulfotransferase encoded by $s x t N$ is predicted to transfer a sulfate group to either $N-21$ or $O-22$. Interestingly, the $s x t$ gene cluster also encodes an adenylylsulfate kinase (APSK), SxtO, putatively involved in the formation of PAPS. Other biosynthetic gene clusters that result in sulfated secondary metabolites also contain genes required for the production of PAPS [126].

Decarbamoylated analogs of STX could be produced via either of two hypothetical scenarios. Enzymes that act downstream of SxtI, the carbamoyltransferase, in the biosynthesis of PSP toxins are proposed to exhibit broad substrate specificity, processing both carbamoylated and decarbamoylated precursors of STX. Alternatively, hydrolytic cleavage of the carbamoyl moiety from STX or its precursors may occur. SxtL is related to GDSL lipases, which are multifunctional enzymes with thioesterase, arylesterase, protease, and lysophospholipase activities [127]. The function of SxtL could therefore include the hydrolytic cleavage of the carbamoyl group from STX analogs. 
Kinetic studies of PSP toxin accumulation in producing cells and the media of cyanobacterial cultures suggest that there is an active transport mechanism for these toxins [85]. In addition, variations in the concentration of sodium in culture media are known to affect the accumulation of PSP toxins in producer cells [128]. sxtF and sxtM encoded two proteins with high sequence similarity to sodiumdriven multidrug and toxic compound extrusion (MATE) proteins of the NorM family. Members of the NorM family of MATE proteins are bacterial sodium-driven antiporters that export cationic substances [129]. All of the PSP toxins are cationic substances, except for the $\mathrm{C}$ toxins, which are zwitterionic. It is therefore probable that SxtF and SxtM are also involved in the export of PSP toxins.

Environmental factors such as nutrient (e.g., nitrogen and phosphate) content, salinity and temperature have been reported to regulate the production of PSP toxins in dinoflagellates and cyanobacteria [130-132]. Two transcriptional factors, sxtY and sxtZ, related to PhoU and OmpR, respectively, as well as a two-component regulator histidine kinase proximal to the $3^{\prime}$ end of the sxt gene cluster in C. raciborskii T3 have been identified. PhoU-related proteins are negative regulators of phosphate uptake [133], whereas OmpR-like proteins are involved in the regulation of a variety of metabolisms, including nitrogen [134] and osmotic balance [135]. It is therefore likely that PSP toxin production in C. raciborskii $\mathrm{T} 3$ may be regulated at the transcriptional level in response to the availability of phosphate as well as other environmental factors.

Figure 7. Structure of the paralytic shellfish toxin biosynthesis cluster (sxt) from; (a) Aphanizomenon sp. NH-5, (b) Anabaena circinalis AWQC131C, (c) Cylindrospermopsis raciborskii T3. Scale indicates gene length in kilobase pairs. Full bars and the letters A-E indicate common features between the various sxt gene clusters.
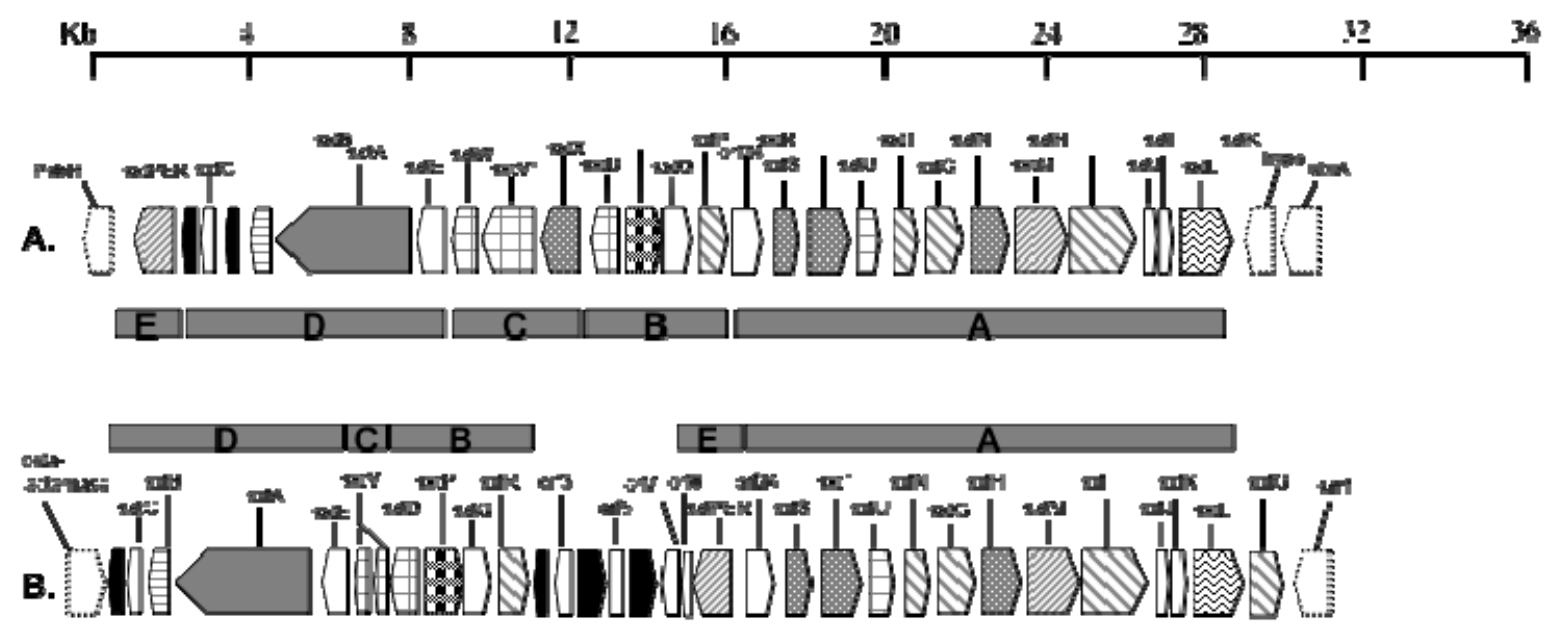

c.
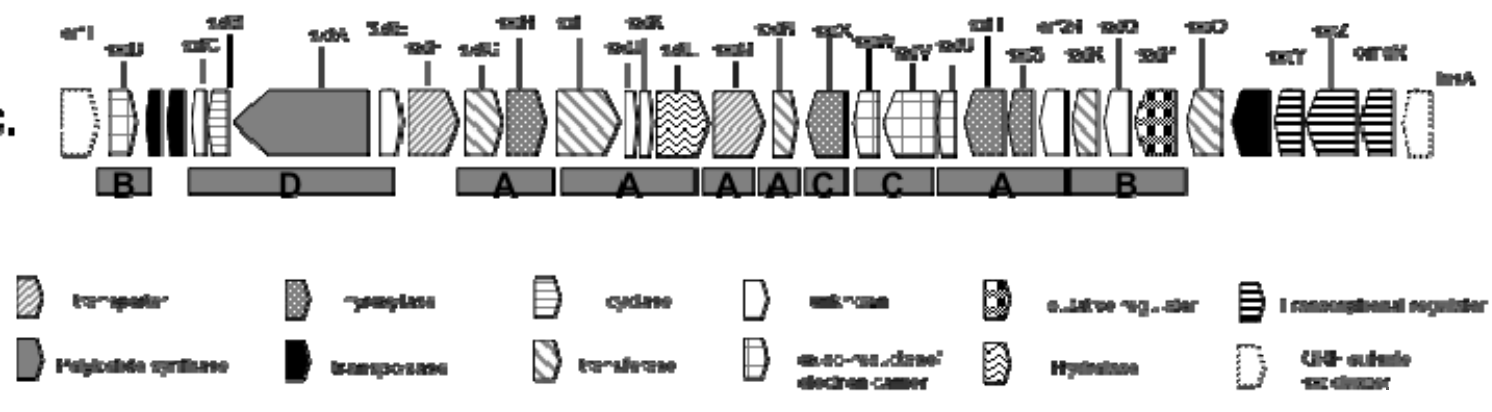
Following the identification and characterisation of the sxt cluster from C. raciborskii, Mihali et al. [136] have described similar gene clusters from an Australian isolate of Anabaena circinalis and an American isolate of Aphanizomenon sp. (Figure $7 \mathrm{~b}$ and a, respectively). These saxitoxin gene clusters are slightly smaller than the $C$. raciborskii, spanning approximately $28 \mathrm{~kb}$. The topology of all three $s x t$ clusters is also varied which suggests the occurrence of multiple transposition events throughout the evolution of saxitoxin biosynthesis in the cyanobacteria. Phylogenetic analysis of the sxt $O$-carbamoyltransferase gene across several saxitoxin producing species indicated that the most likely origin of the gene was an ancestral a-proteobacterium and that the entire set of genes required for saxitoxin biosynthesis probably spread by horizontal gene transfer [137].

Figure 8. Proposed saxitoxin biosynthetic pathway in cyanobacteria based on intermediate characterization and bioinformatic analysis. Dashed lines indicate possible alternative reactions [see text for detailed steps].
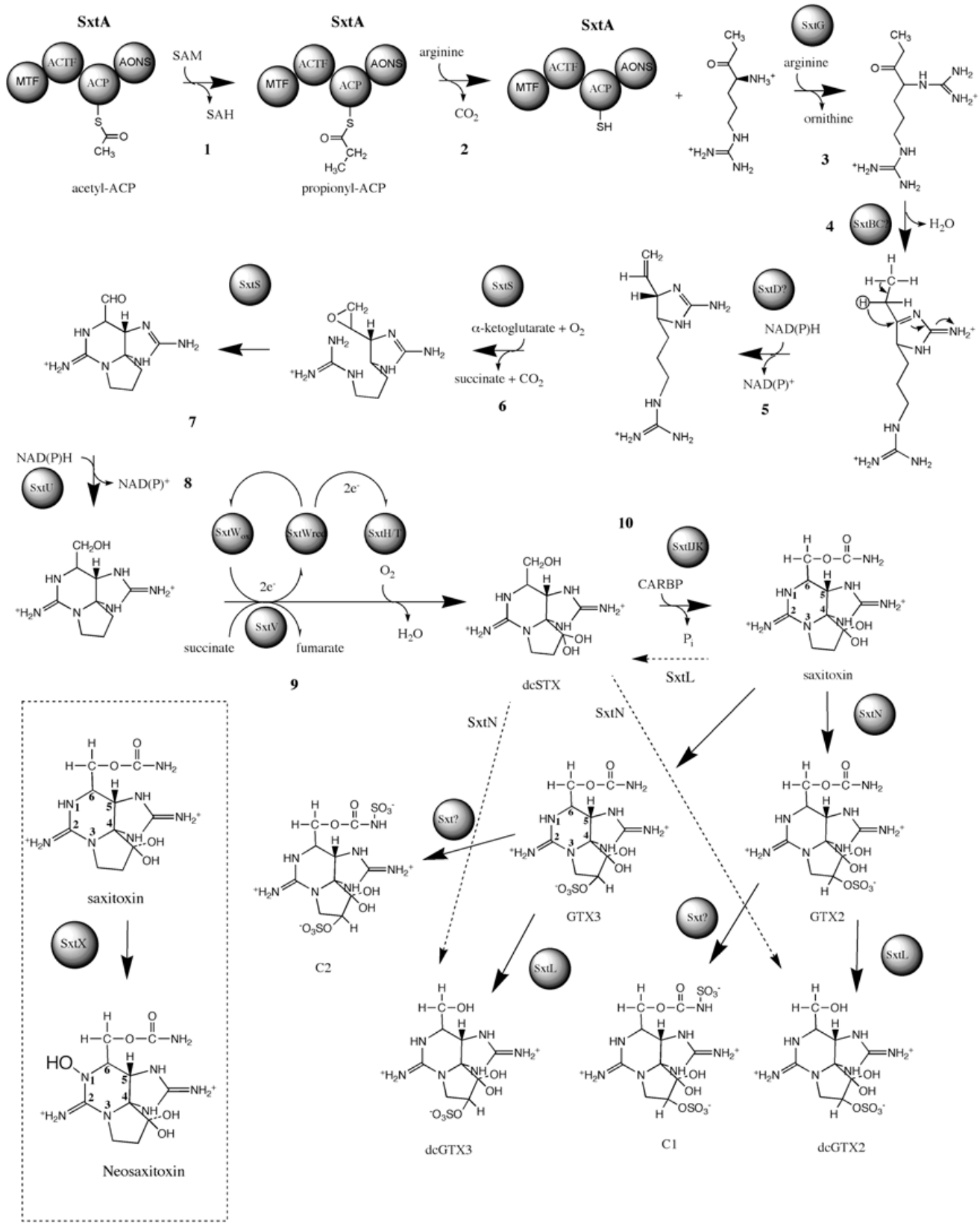


\section{Cylindrospermopsin}

\subsection{Introduction}

The cyanobacterial alkaloid toxin, cylindrospermopsin, was first identified in 1979 when 148 people were hospitalized with symptoms of hepatoenteritis on Palm Island (Queensland, Australia). This outbreak was later linked to a bloom of Cylindrospermopsis raciborskii in a drinking water reservoir $[138,139]$. In addition to its impact on human health, cylindrospermopsin poisonings have been linked to the death of domestic animals [140].

Eight cyanobacterial species have thus far been identified as cylindrospermopsin producers; Cylindrospermopsis raciborskii, Aphanizomenon ovalisporum, Aphanizomenon flos-aquae, Umezakia natans, Rhaphdiopsis curvata and Anabaena bergii, Anabaena lapponica, and Lygnbya wollei [141-148]. The wide distribution of cylindrospermopsin producing species, coupled with the invasiveness of the chief toxin producer, C. raciborskii, presents a major problem for water management, on a global scale [149].

\subsection{Chemistry}

Cylindrospermopsin is a polyketide-derived alkaloid with a central functional guanidino moiety and a hydroxymethyluracil attached to the tricyclic carbon skeleton [150] (Figure 9). The natural occurrence of an epimer at the hydroxyl bridge, 7-epicylindrospermopsin [151], and a cylindrospermopsin variant lacking the hydroxyl group at C7, 7-deoxycylindrospermopsin, have also been reported [143].

Figure 9. The chemical structure of the NRPS and PKS derived alkaloid cylindrospermopsin. Natural variants containing an epimer at the hydroxyl bridge (C7) or lacking the hydroxyl altogether have also been reported [151].

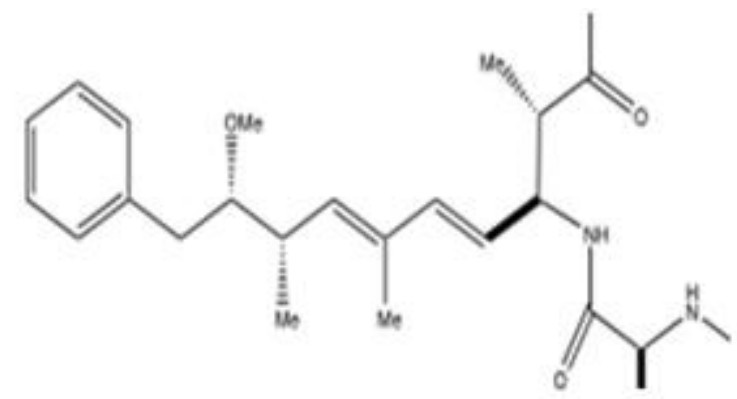

\subsection{Toxicology}

Cylindrospermopsin is a highly biologically active alkaloid, interfering with several metabolic pathways. It has hepatotoxic, general cytotoxic [152-154] and neurotoxic [155] effects and is considered a potential carcinogen [156]. The toxicity of cylindrospermopsin is mediated through the inhibition of glutathione, protein synthesis and cytochrome P450 [152-154,157], with the uracil moiety as well as the hydroxyl at C7 being crucial for toxicity [158,151]. In mammals, cylindrospermopsin poisoning can cause liver, kidney, thymus and heart damage $[159,160]$. 


\subsection{Biosynthesis and Genetics}

The cylindrospermopsin biosynthesis (cyr) gene cluster from C. raciborskii AWT205 was recently sequenced [161] The cluster spans $43 \mathrm{~kb}$ and contains 15 ORFs, which encode all the functions required for the biosynthesis, regulation and export of the toxin (Figure 10). Biosynthesis is initiated via an amidinotransfer onto glycine followed by five polyketide extensions and subsequent reductions, rings are formed via Michael additions in a step-wise manner. The uracil ring is formed by a novel pyrimidine biosynthesis mechanism and tailoring reactions, including sulfation and hydroxylation that complete biosynthesis (Figure 11).

Figure 10. Structural organization of the cylindrospermopsin gene cluster from C. raciborskii AWT205. Scale indicates gene cluster in base pairs.

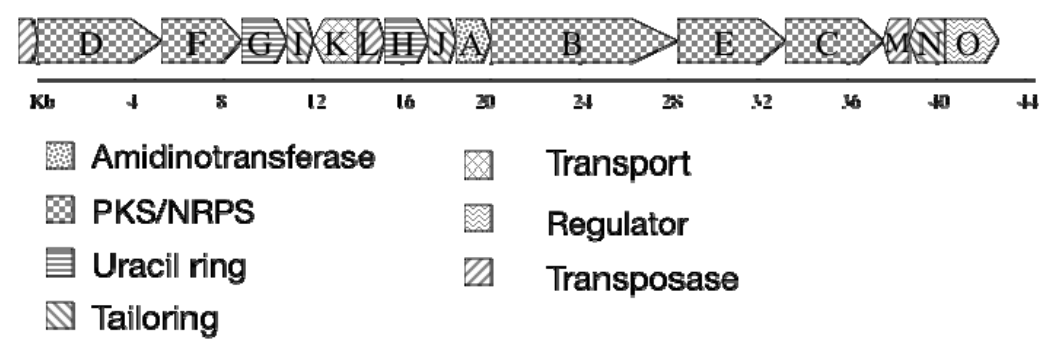

Figure 11. Proposed biosynthetic pathway for cylindrospermopsin (see text for detail).

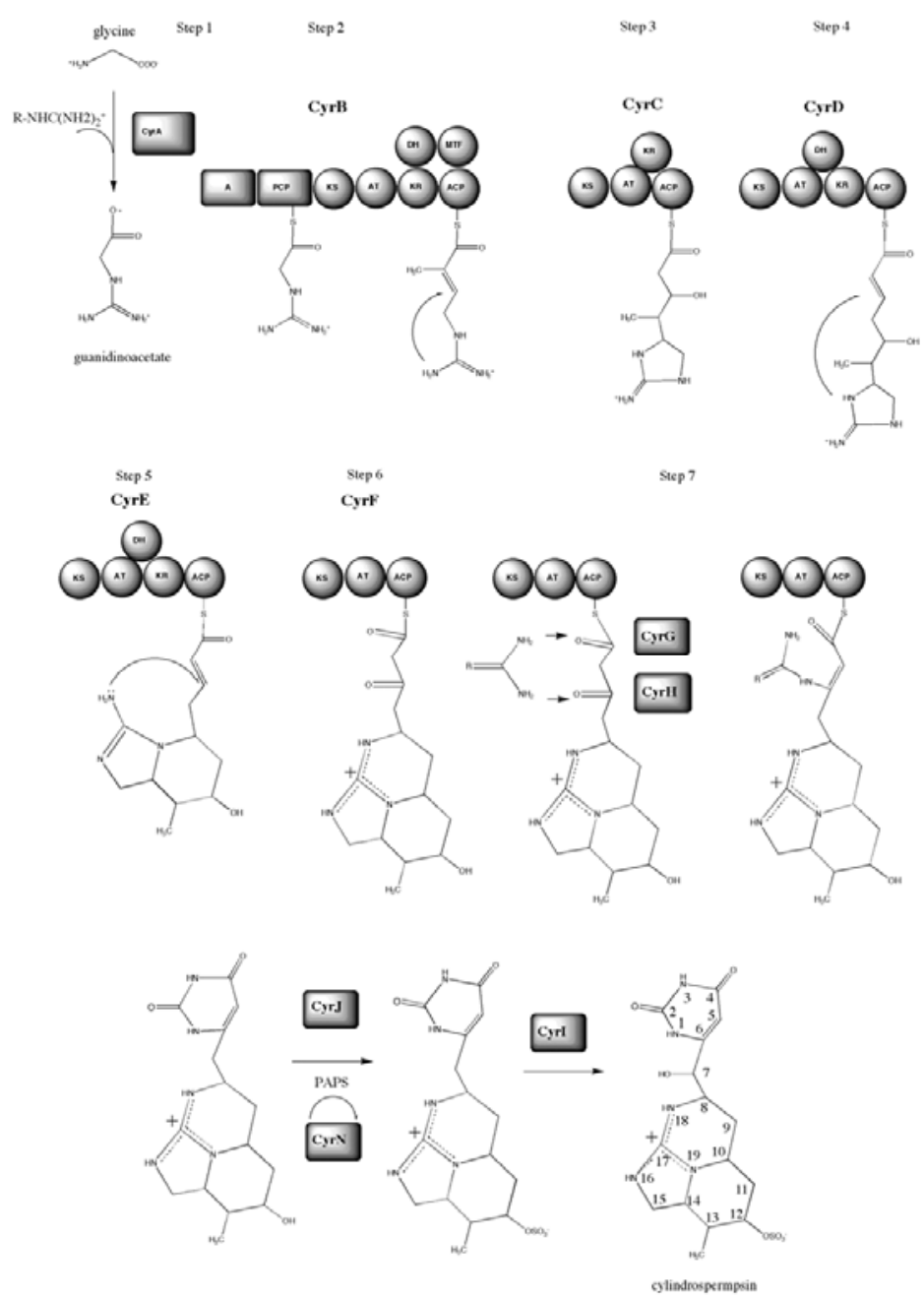


The first step in formation of the carbon skeleton of cylindrospermopsin involves the synthesis of guanidinoacetate via the transamidination of glycine [162-164]. An amidinotransferase encoded by cyrA, putatively transfers a guanidino group from arginine [163], to glycine thus forming guanidinoacetate. A mixed NRPS-PKS encoded by $c y r B$ is thought to activate guanidinoacetate, which is then transferred via the swinging arm of the peptidyl carrier protein (PCP) to the KS domain. The AT domain of CyrB activates malonyl-CoA and attaches it to the ACP. This is followed by a condensation reaction between the activated guanidinoacetate and malonyl-CoA in the KS domain. The methyl transferase (MT) domain identified in $\mathrm{CyrB}$ is predicted to methylate C13. CyrB contains two reducing modules, KR and $\mathrm{DH}$. Their concerted reaction reduces the keto group to a hydroxyl followed by elimination of $\mathrm{H}_{2} \mathrm{O}$, resulting in a double bond between $\mathrm{C} 13$ and $\mathrm{C} 14$. A nucleophilic attack of the amidino group at N19 onto the newly formed double bond between C13 and C14 then putatively occurs via a 'Michael addition'. The cyclization follows Baldwin's rules for ring closure [165], resulting in the formation of the first ring in cylindrospermopsin. This reaction could be spontaneous and may not require enzymatic catalysis, as it is energetically favorable [165]. This is the first of three ring formations and is one of the principal differences between Mihali et al.'s [161] biosynthetic pathway and that previously proposed [163].

The third step in the biosynthesis of cylindrospermopsin involves cyrC, which encodes a PKS with KS, AT, KR, and ACP domains. The action of these domains results in the elongation of the growing chain by an acetate via activation of malonyl-CoA by the AT domain, its transfer to ACP and condensation at the KS domain with the product of CyrB. The elongated chain is bound to the ACP of $\mathrm{CyrC}$ and the $\mathrm{KR}$ domain reduces the keto group to a hydroxyl group on C12. Following the catalysis of enzyme CyrC is CyrD, a PKS. The action of this PKS module on the product of CyrC results in the addition of one acetate and the reduction of the keto group on C10 to a hydroxyl and dehydration to a double bond between $\mathrm{C} 9$ and $\mathrm{C} 10$. This double bond is the site of a nucleophilic attack by the amidino group N19 via another Michael addition that again follows Baldwin's rules of ring closure [165], resulting in the formation of the second ring, the first six-membered ring made in cylindrospermopsin. The intermediate produced by CyrD is the substrate for CyrE (step 5 in Figure 1). A PKS, CyrE, catalyzes the addition of one acetate and the formation of a double bond between $\mathrm{C} 7$ and $\mathrm{C} 8$. This double bond is attacked by N18 via a Michael addition and the third cyclisation occurs, resulting in the second 6-member ring. The cyrF gene encodes the final PKS module - a minimal PKS containing only a KS, AT, and ACP. CyrF acts on the product of CyrE and elongates the chain by an acetate, leaving $\mathrm{C} 4$ and C6 unreduced. Step 7 in the pathway involves the formation of the uracil ring, a reaction that has been elusive so far and is required for the toxicity of the final cylindrospermopsin compound [151].

The cylindrospermopsin gene cluster encodes two enzymes $\mathrm{CyrG}$ and $\mathrm{CyrH}$ that are most similar to the enzyme family of amidohydrolases/ureases/dihydrotases, whose members catalyze the formation and cleavage of N-C bonds. Mihali and co-workers [161] propose that these enzymes transfer a second guanidino group from a donor molecule, such as arginine or urea, onto C6 and C4 of cylindrospermopsin resulting in the formation of the uracil ring. The first reaction consists of the formation of a covalent bond between the $\mathrm{N}$ of the guanidino donor and $\mathrm{C} 6$ of cylindrospermopsin followed by an elimination of $\mathrm{H}_{2} \mathrm{O}$ forming a double bond between $\mathrm{C} 5$ and $\mathrm{C} 6$. The second reaction catalyses the formation of a bond between the second $\mathrm{N}$ on the guanidino donor and $\mathrm{C} 4$ of 
cylindrospermopsin, co-committently with the breaking of the thioester bond between the acyl carrier protein of $\mathrm{CyrF}$ and cylindrospermopsin, causing the release of the molecule from the enzyme complex. The third reaction - if required - would catalyze the cleavage of the guanidino group from a donor molecule other than urea. The action of $\mathrm{CyrG}$ and $\mathrm{CyrH}$ in the formation of the uracil ring in cylindrospermopsin describes a novel biosynthesis pathway of a pyrimidine. Mihali and co-workers' [161] genetic analysis shows that cyclization may happen stepwise, with successive ring formation of the appropriate intermediate as it is synthesized. This mechanism also explains the lack of a thioesterase or cyclization domain, which are usually associated with NRPS/PKS modules and catalyze the release and cyclization of the final product from the enzyme complex.

The sulfation of cylindrospermopsin at $\mathrm{C} 12$ is likely to be carried out by the action of a sulfotransferase. The cyrJ gene encodes a protein that is most similar to human 3'-phosphoadenylyl sulfate (PAPS) dependent sulfotransferases. Similar enzymes have recently been implicated in the sulfation of other cyanotoxins [120]. The cylindrospermopsin gene cluster also encodes an adenylsulfate kinase (ASK), namely CyrN. ASKs are enzymes that catalyse the formation of PAPS, which is the sulfate donor for sulfotransferases. Mihali and co-workers [161] propose that CyrJ sulfates cylindrospermopsin at $\mathrm{C} 12$ while CyrN creates the pool of PAPS required for this reaction. Screening of cylindrospermopsin producing and non-producing strains revealed that the sulfotransferase genes were only present in cylindrospermopsin producing strains, further affirming the involvement of this entire cluster in the biosynthesis of cylindrospermopsin. The cyrJ gene might therefore be a good candidate for a toxin probe, as it is more unique than NRPS and PKS genes and would presumably have less cross-reactivity with other gene clusters containing these genes, which are common in cyanobacteria. The final tailoring reaction is carried out by CyrI. CyrI putatively catalyzes the hydroxylation of $\mathrm{C} 7$, a residue that, along with the uracil ring, seems to confer much of the toxicity of cylindrospermopsin [158,166].

The cylindrospermopsin gene cluster contains an ORF denoted cyrK, the product of which is most similar to sodium ion driven multi-drug and toxic compound extrusion proteins (MATE) of the NorM family. CyrK is hypothesized to function as a transporter for cylindrospermopsin, based on this homology and its central location in the cluster.

Cylindrospermopsin production has been shown to be highest when fixed nitrogen is eliminated from the growth media [167]. Flanking the cylindrospermopsin gene cluster are "hyp" gene homologs involved in the maturation of hydrogenases. In the cyanobacterium Nostoc PCC73102 they are under the regulation of the global nitrogen regulator NtcA, that activates transcription of nitrogen assimilation genes $[168,169]$. It is plausible that the cylindrospermopsin gene cluster is under the same regulation, as it is located wholly within the "hyp" gene cluster in C. raciborskii AWT205, and no obvious promoter region in the cylindrospermopsin gene cluster could be identified. Finally, the cylindrospermopsin cluster also includes an ORF at its 3'-end designated CyrO. By homology, it encodes a hypothetical protein that appears to possess an ATP binding cassette, and is similar to WD repeat proteins, which have diverse regulatory and signal transduction roles. CyrO may also have a role in transcriptional regulation and DNA binding. It also shows homology to AAA family proteins that often perform chaperone-like functions and assist in the assembly, operation, or disassembly of protein complexes. Further insights into the role of $\mathrm{CyrO}$ are hindered due to low sequence homology with other proteins in databases. 


\section{References and Notes}

1. Sivonen, K.; Jones, G. Toxic Cyanobacteria in Water: A Guide to Their Public Health consequences, Monitoring and Management; E and FN Spon: New York, NY, USA, 1999; Volume 1, pp. 40-111.

2. Welker, M.; von Dohren, H. Cyanobacterial peptides - nature's own combinatorial biosynthesis. FEMS Microbiol. Rev. 2006, 30, 530-563.

3. Botes, D.; Wessels, P.; Kruger, H.; Runnegar, M.; Santikarn, S.; Smith, R.; Barna, J.; Williams, D. Structural studies on cyanoginosins-LR, -YR, -YA, and -YM, peptide toxins from Microcystis aeruginosa. . J. Chem. Soc. 1985, 1, 2747-2748.

4. Namikoshi, M.; Yuan, M.; Sivonen, K.; Carmichael, W.W.; Rinehart, K.L.; Rouhiainen, L.; Sun, F.; Brittain, S.; Otsuki, A. Seven new microcystins possessing two L-glutamic acid units, isolated from Anabaena sp. strain 186. Chem. Res. Toxicol. 1998, 11, 143-149.

5. Rinehart, K.; Namikoshi, N.; Choi, B. Structure and biosynthesis of toxins from blue-green algae (cyanobacteria). J. App. Phycol. 1994, 6, 159-176.

6. Sivonen, K. Cyanobacterial toxins and toxin production. Phycologia 1996, 35, 12-24.

7. Chorus, I.; Bartram, J. Toxic Cyanobacteria in Water. A Guide to their Public Health Consequences, Monitoring and Management; E \& FN Spon: London, UK, 1999.

8. Jochimsen, E.M.; Carmichael, W.W.; An, J.S.; Cardo, D.M.; Cookson, S.T.; Holmes, C.E.; Antunes, M.B.; de Melo Filho, D.A.; Lyra, T.M.; Barreto, V.S.; Azevedo, S.M.; Jarvis, W.R. Liver failure and death after exposure to microcystins at a hemodialysis center in Brazil. N. Engl. J. Med. 1998, 338, 873-878.

9. Runnegar, M.T.; Gerdes, R.G.; Falconer, I.R. The uptake of the cyanobacterial hepatotoxin microcystin by isolated rat hepatocytes. Toxicon 1991, 29, 43-51.

10. Runnegar, M.; Berndt, N.; Kaplowitz, N. Microcystin uptake and inhibition of protein phosphatases: effects of chemoprotectants and self-inhibition in relation to known hepatic transporters. Toxicol. Appl. Pharmacol. 1995, 134, 264-272.

11. Dawson, R.M. The toxicology of microcystins. Toxicon 1998, 36, 953-962.

12. Eriksson, J.E.; Toivola, D.; Meriluoto, J.A.; Karaki, H.; Han, Y.G.; Hartshorne, D. Hepatocyte deformation induced by cyanobacterial toxins reflects inhibition of protein phosphatases. Biochem. Biophys. Res. Commun. 1990, 173, 1347-1353.

13. Sahin, A.; Tencalla, F.G.; Dietrich, D.R.; Mez, K.; Naegeli, H. Enzymatic analysis of liver samples from rainbow trout for diagnosis of blue-green algae-induced toxicosis. Am. J. Vet. Res. 1995, 56, 1110-1115.

14. Krishnamurthy, T.; Carmichael, W.W.; Sarver, E.W. Toxic peptides from freshwater cyanobacteria (blue-green algae). I. Isolation, purification and characterization of peptides from Microcystis aeruginosa and Anabaena flos-aquae. Toxicon 1986, 24, 865-873.

15. Watanabe, M.F.; Oishi, S.; Harda, K.; Matsuura, K.; Kawai, H.; Suzuki, M. Toxins contained in Microcystis species of cyanobacteria (blue-green algae). Toxicon 1988, 26, 1017-1025.

16. Yoshizawa, S.; Matsushima, R.; Watanabe, M.F.; Harada, K.; Ichihara, A.; Carmichael, W.W.; Fujiki, H. Inhibition of protein phosphatases by microcystins and nodularin associated with hepatotoxicity. J. Cancer Res. Clin. Oncol. 1990, 116, 609-614. 
17. Nishiwaki, S.; Fujiki, H.; Suganuma, M.; Nishiwaki-Matsushima, R.; Sugimura, T. Rapid purification of protein phosphatase 2A from mouse brain by microcystin-affinity chromatography. FEBS Lett. 1991, 279, 115-118.

18. Falconer, I.R. Tumor promotion and liver injury caused by oral consumption of cyanobacteria. Environ. Toxicol. Water Qual. 1991, 6, 177-184.

19. Nishiwaki-Matsushima, R.; Ohta, T.; Nishiwaki, S.; Suganuma, M.; Kohyama, K.; Ishikawa, T.; Carmichael, W.W.; Fujiki, H. Liver tumor promotion by the cyanobacterial cyclic peptide toxin microcystin-LR. J. Cancer Res. Clin. Oncol. 1992, 118, 420-424.

20. $\mathrm{Yu}, \mathrm{S}$. Primary prevention of hepatocellular carcinoma. J. Gastroenterol. Hepatol. 1995, 10, 674-682.

21. Yu, S. Drinking Water and Primary Liver Cancer; China academic publishers: New York, NY, USA, 1989.

22. Tillett, D.; Dittmann, E.; Erhard, M.; von Dohren, H.; Borner, T.; Neilan, B.A. Structural organization of microcystin biosynthesis in Microcystis aeruginosa PCC7806: an integrated peptide-polyketide synthetase system. Chem. Biol. 2000, 7, 753-764.

23. Christiansen, G.; Fastner, J.; Erhard, M.; Borner, T.; Dittmann, E. Microcystin biosynthesis in planktothrix: genes, evolution, and manipulation. J. Bacteriol. 2003, 185, 564-572.

24. Rouhiainen, L.; Vakkilainen, T.; Siemer, B.L.; Buikema, W.; Haselkorn, R.; Sivonen, K. Genes coding for hepatotoxic heptapeptides (microcystins) in the cyanobacterium Anabaena strain 90. Appl. Environ. Microbiol. 2004, 70, 686-692.

25. Hicks, L.M.; Moffitt, M.C.; Beer, L.L.; Moore, B.; Kelleher, N.L. Structural characterisation of in vitro and in vivo intermediates on the loading module of microcystin synthetase. ACS Chem. Biol. 2006, 1, 93-102.

26. Nishizawa, T.; Asayama, M.; Shirai, M. Cyclic heptapeptide microcystin biosynthesis requires the glutamate racemase gene. Microbiology 2001, 147, 1235-1241.

27. Sielaff, H.; Dittmann, E.; Tandeau De Marsac, N.; Bouchier, C.; Von Dohren, H.; Borner, T.; Schwecke, T. The mcyF gene of the microcystin biosynthetic gene cluster from Microcystis aeruginosa encodes an aspartate racemase. Biochem. J. 2003, 373, 909-916.

28. Pearson, L.A.; Barrow, K.D.; Neilan, B.A. Characterization of the 2-hydroxy-acid dehydrogenase McyI, encoded within the microcystin biosynthesis gene cluster of Microcystis aeruginosa PCC7806. J. Biol. Chem. 2007, 282, 4681-4692.

29. Pearson, L.A.; Hisbergues, M.; Borner, T.; Dittmann, E.; Neilan, B.A. Inactivation of an ABC transporter gene, mcyH, results in loss of microcystin production in the cyanobacterium Microcystis aeruginosa PCC 7806. Appl. Environ. Microbiol. 2004, 70, 6370-6378.

30. Shi, L.; Carmichael, W.W.; Miller, I. Immuno-gold localization of hepatotoxins in cyanobacterial cells. Arch. Microbiol. 1995, 163, 7-15.

31. Young, F.M.; Thomson, C.; Metcalf, J.S.; Lucocq, J.M.; Codd, G.A. Immunogold localisation of microcystins in cryosectioned cells of Microcystis. J. Struct. Biol. 2005, 151, 208-214.

32. Kaebernick, M.; Neilan, B.A.; Borner, T.; Dittmann, E. Light and the transcriptional response of the microcystin biosynthesis gene cluster. Appl. Environ. Microbiol. 2000, 66, 3387-3392. 
33. Mikalsen, B.; Boison, G.; Skulberg, O.M.; Fastner, J.; Davies, W.; Gabrielsen, T.M.; Rudi, K.; Jakobsen, K.S. Natural variation in the microcystin synthetase operon mcyABC and impact on microcystin production in Microcystis strains. J. Bacteriol. 2003, 185, 2774-2785.

34. Tooming-Klunderud, A.; Mikalsen, B.; Kristensen, T.; Jakobsen, K.S. The mosaic structure of the mcyABC operon in Microcystis. Microbiology 2008, 154, 1886-1899.

35. Sivonen, K. Effects of light, temperature, nitrate, orthophosphate, and bacteria on growth of and hepatotoxin production by Oscillatoria agardhii strains. Appl. Environ. Microbiol. 1990, 56, 2658-2666.

36. Lukac, M.; Aegerter, R. Influence of trace metals on growth and toxin production of Microcystis aeruginosa. Toxicon 1993, 31, 293-305.

37. van der Westhuizen, A.J.; Eloff, J.N. Effect of temperature and light on the toxicity and growth of the blue-green alga Microcystis aeruginosa (UV-006). Planta 1985, 163, 55-59.

38. Song, L.; Sano, T.; Li, R.; Watanabe, M.; Liu, Y.; Kaya, K. Microcystin production of Microcystis viridis (cyanobacteria) under different culture conditions. Phycol. Res. 1998, 42, 19.

39. Davis, T.W.; Berry, D.L.; Boyer, G.L.; Gobler, C.J. The effects of temperature and nutrients on the growth and dynamics of toxic and non-toxic strains of Microcystis during cyanobacteria blooms. Harmful Algae 2009, 8, 715-725.

40. Tonk, L.; Visser, P.M.; Christiansen, G.; Dittmann, E.; Snelder, E.O.; Wiedner, C.; Mur, L.R.; Huisman, J. The microcystin composition of the cyanobacterium Planktothrix agardhii changes toward a more toxic variant with increasing light intensity. Appl. Environ. Microbiol. 2005, 71, 5177-5181.

41. Sevilla, E.; Martin-Luna, B.; Vela, L.; Bes, M.T.; Fillat, M.F.; Peleato, M.L. Iron availability affects mcyD expression and microcystin-LR synthesis in Microcystis aeruginosa PCC7806. Environ. Microbiol. 2008, 10, 2476-2483.

42. Kaebernick, M.; Dittmann, E.; Borner, T.; Neilan, B.A. Multiple alternate transcripts direct the biosynthesis of microcystin, a cyanobacterial nonribosomal peptide. Appl. Environ. Microbiol. 2002, 68, 449-455.

43. Sivonen, K.; Kononen, K.; Carmichael, W.W.; Dahlem, A.M.; Rinehart, K.L.; Kiviranta, J.; Niemela, S.I. Occurrence of the hepatotoxic cyanobacterium Nodularia spumigena in the Baltic Sea and structure of the toxin. Appl. Environ. Microbiol. 1989, 55, 1990-1995.

44. Jones, G.J.; Blackburn, S.I.; Parker, N.S. A toxic bloom of Nodularia spumigena mertens in Orielton Lagoon, Tasmania. Aust. J. Mar. Freshwater Res. 1994, 45, 787-800.

45. Heresztyn, T.; Nicholson, B.C. Nodularin concentrations in Lakes Alexandrina and Albert, South Australia, during a bloom of the cyanobacterium (blue-green alga) Nodularia spumigena and degradation of the toxin. Environ. Toxicol. Water Qual. 1997, 12, 273-282.

46. Nehring, S. Mortality of dogs associated with a mass development of Nodularia spumigena (Cyanophyceae) in a brackish lake at the German North Sea coast. J. Plankton Res. 1993, 15, 867-872.

47. Carmichael, W.W.; Eschedor, J.T.; Patterson, G.M.; Moore, R.E. Toxicity and partial structure of a hepatotoxic peptide produced by the cyanobacterium Nodularia spumigena Mertens emend. L575 from New Zealand. Appl. Environ. Microbiol. 1988, 54, 2257-2263. 
48. Galat, D.L.; Verdin, J.P.; Sims, L.L. Large-scale patterns of Nodularia spumigena blooms in Pyramid Lake, Nevada, determined from Landsat imagery: 1972-1986. Hydrobiologia 1990, 197, 147-164.

49. Baker, P.D.; Humpage, A.R. Toxicity associated with commonly occurring cyanobacteria in surface waters of the Murray-Darling Basin, Australia. Aust. J. Mar. Freshwater Res. 1994, 45, 773-786.

50. Karjalainen, M.; Engstrom-Ost, J.; Korpinen, S.; Peltonen, H.; Paakkonen, J.P.; Ronkkonen, S.; Suikkanen, S.; Viitasalo, M. Ecosystem consequences of cyanobacteria in the northern Baltic Sea. Ambio 2007, 36, 195-202.

51. Carmichael, W.W. The Toxins of Cyanobacteria. Sci. Am. 1994, 64-72.

52. Francis, G. Poisonous Australian lake. Nature 1878, 18, 11-12.

53. Ohta, T.; Sueoka, E.; Iida, N.; Komori, A.; Suganuma, M.; Nishiwaki, R.; Tatematsu, M.; Kim, S.J.; Carmichael, W.W.; Fujiki, H. Nodularin, a potent inhibitor of protein phosphatases 1 and 2A, is a new environmental carcinogen in male F344 rat liver. Cancer Res. 1994, 54, 6402-6406.

54. Van Buynder, P.G.; Oughtred, T.; Kirkby, B.; Phillips, S.; Eaglesham, G.; Thomas, K.; Burch, M. Nodularin uptake by seafood during a cyanobacterial bloom. Environ. Toxicol. 2001, 16, 468-471.

55. Falconer, I.R.; Choice, A.; Hosja, W. Toxicity of edible mussels Mytilus edulis growing naturally in an estuary during a water bloom of the blue-green alga Nodularia spumigena. Environ. Toxicol. Water Qual. 1992, 7, 119-123.

56. Mazur-Marzec, H.; Tyminska, A.; Szafranek, J.; Plinski, M. Accumulation of nodularin in sediments, mussels, and fish from the Gulf of Gdansk, southern Baltic Sea. Environ. Toxicol. 2007, 22, 101-111.

57. Rinehart, K.L.; Harada, K.; Namikoshi, M.; Chen, C.; Harvis, C.A.; Munro, M.H.G.; Blunt, J.W.; Mulligan, P.E.; Beasley, V.R.; Dahlem, A.M.; Carmicheal, W.W. Nodularin, microcystin, and the configuration of Adda. J. Am. Chem. Soc. 1988, 110, 8557-8558.

58. Saito, K.; Konno, A.; Ishii, H.; Saito, H.; Nishida, F.; Abe, T.; Chen, C. Nodularin-Har: a new nodularin from Nodularia. J. Nat. Prod. 2001, 64, 139-141.

59. Beattie, K.A.; Kaya, K.; Codd, G.A. The cyanobacterium Nodularia PCC7804, of freshwater origin, produces [L-Har2]nodularin. Phytochemistry 2000, 54, 57-61.

60. deSilva, E.D.; Williams, D.E.; Anderson, R.J.; Klix, H.; Holmes, C.F.B.; Allen, T.M. Motuporin, a potent protein phosphatase inhibitor isolated from the Papua New Guinea sponge Theonella swinhoei Gray. Tetrahedron Lett. 1992, 33, 1561-1564.

61. Eriksson, J.E.; Meriluoto, J.A.; Kujari, H.P.; Osterlund, K.; Fagerlund, K.; Hallbom, L. Preliminary characterization of a toxin isolated from the cyanobacterium Nodularia spumigena. Toxicon 1988, 26, 161-166.

62. Honkanen, R.E.; Dukelow, M.; Zwiller, J.; Moore, R.E.; Khatra, B.S.; Boynton, A.L. Cyanobacterial nodularin is a potent inhibitor of type 1 and type 2A protein phosphatases. Mol. Pharmacol. 1991, 40, 577-583.

63. An, J.; Carmichael, W.W. Use of a colorimetric protein phosphatase inhibition assay and enzyme linked immunosorbent assay for the study of microcystins and nodularins. Toxicon 1994, 32, $1495-1507$. 
64. MacKintosh, R.W.; Dalby, K.N.; Campbell, D.G.; Cohen, P.T.; Cohen, P.; MacKintosh, C. The cyanobacterial toxin microcystin binds covalently to cysteine-273 on protein phosphatase 1 . FEBS Lett. 1995, 371, 236-240.

65. Kelker, M.S.; Page, R.; Peti, W. Crystal structures of protein phosphatase-1 bound to nodularin$\mathrm{R}$ and tautomycin: a novel scaffold for structure-based drug design of serine/threonine phosphatase inhibitors. J. Mol. Biol. 2009, 385, 11-21.

66. Runnegar, M.; Berndt, N.; Kong, S.M.; Lee, E.Y.; Zhang, L. In vivo and in vitro binding of microcystin to protein phosphatases 1 and 2A. Biochem. Biophys. Res. Commun. 1995, 216, $162-169$.

67. Bagu, J.R.; Sykes, B.D.; Craig, M.M.; Holmes, C.F. A molecular basis for different interactions of marine toxins with protein phosphatase-1. Molecular models for bound motuporin, microcystins, okadaic acid, and calyculin A. J. Biol. Chem. 1997, 272, 5087-5097.

68. Karjalainen, M.; Pääkkönen, J.; Peltonen, H.; Sipiä, V.; Valtonen, T.; Viitasalo, M. Nodularin concentrations in Baltic Sea zooplankton and fish during a cyanobacterial bloom. Mar. Biol. 2008, 155, 483-491.

69. Persson, K.; Legrand, C.; Olsson, T. Detection of nodularin in European flounder (Platichthys flesus) in the west coast of Sweden: Evidence of nodularin mediated oxidative stress. Harmful Algae 2009, 8, 832-838.

70. Vuorinen, P.J.; Sipia, V.O.; Karlsson, K.; Keinanen, M.; Furey, A.; Allis, O.; James, K.; Perttila, U.; Rimaila-Parnanen, E.; Meriluoto, J.A. Accumulation and effects of nodularin from a single and repeated oral doses of cyanobacterium Nodularia spumigena on flounder (Platichthys flesus L.). Arch. Environ. Contam. Toxicol. 2009, 57, 164-173.

71. Moffitt, M.C.; Neilan, B.A. Characterization of the nodularin synthetase gene cluster and proposed theory of the evolution of cyanobacterial hepatotoxins. Appl. Environ. Microbiol. 2004, $70,6353-6362$.

72. Kleinkauf, H.; Von Dohren, H. A nonribosomal system of peptide biosynthesis. Eur. J. Biochem. 1996, 236, 335-351.

73. Copp, J.N.; Roberts, A.A.; Marahiel, M.A.; Neilan, B.A. Characterization of PPTNs, a cyanobacterial phosphopantetheinyl transferase from Nodularia spumigena NSOR10. $J$. Bacteriol. 2007, 189, 3133-3139.

74. Jonasson, S.; Vintila, S.; Sivonen, K.; El-Shehawy, R. Expression of the nodularin synthetase genes in the Baltic Sea bloom-former cyanobacterium Nodularia spumigena strain AV1. FEMS. Microbiol. Ecol. 2008, 65, 31-39.

75. Negri, A.P.; Jones, G.J.; Hindmarsh, M. Sheep mortality associated with paralytic shellfish poisons from the cyanobacterium Anabaena circinalis. Toxicon 1995, 33, 1321-1329.

76. Reyero, M.; Cacho, E.; Martínez, A.; Vázquez, J.; Marina, A.; Fraga, S.; Franco, J. Evidence of saxitoxin derivatives as causative agents in the 1997 mass mortality of monk seals in the Cape Blanc Peninsula. Nat. Toxins 1999, 7, 311-315.

77. Sawyer, P.J.; Gentile, J.H.; Sasner, J.J.J. Demonstration of a toxin from Aphanisomenon flosaquae (L.) Ralfs. Can. J. Microbiol. 1968, 14, 1199-1204.

78. Shumway, S.E. Phycotoxin-related shellfish poisoning: Bivalve molluscs are not the only vectors. Rev. Fish. Sci. 1995, 3, 1-31. 
79. Shumway, S.E.; Cucci, T.L.; Yentsch, C.M.; Newell, R.C.; Gainey, L. The effects of the toxic dinoflagellate, Protogonyaulax tamarensis, on the physiology and behavior of marine molluscs. J. Shellfish Res. 1988, 7, 132-133.

80. Hallegraeff, G.M. Harmful algal blooms: A global overview. In Manual on Harmful Marine Microalgae; Hallegraeff, G.M.; Anderson, D.M., Cembella, A.D., Eds.; UNESCO: Paris, France, 1995; pp. 1-22.

81. Daly, J.W. Marine toxins and nonmarine toxins: convergence or symbiotic organisms? J. Nat. Prod. 2004, 67, 1211-1215.

82. Baker, T.R.; Doucette, G.J.; Powell, C.L.; Boyer, G.L.; Plumley, F.G. GTX(4) imposters: characterization of fluorescent compounds synthesized by Pseudomonas stutzeri SF/PS and Pseudomonas/Alteromonas PTB-1, symbionts of saxitoxin-producing Alexandrium spp. Toxicon 2003, 41, 339-347.

83. Kodoma, M.; Ogata, T.; Sakamoto, S.; Sato, S.; Honda, T.; Miwatani, T. Production of paralytic shellfish toxins by a bacterium Moraxella sp. isolated from Protogonyaulax tamarensis. Toxicon 1990, 28, 707-714.

84. Martins, C.A.; Alvito, P.; Tavares, M.J.; Pereira, P.; Doucette, G.; Franca, S. Reevaluation of production of paralytic shellfish toxin by bacteria associated with dinoflagellates of the Portuguese coast. Appl. Environ. Microbiol. 2003, 69, 5693-5698.

85. Castro, D.; Vera, D.; Lagos, N.; Garcia, C.; Vasquez, M. The effect of temperature on growth and production of paralytic shellfish poisoning toxins by the cyanobacterium Cylindrospermopsis raciborskii C10. Toxicon 2004, 44, 483-489.

86. Negri, A.; Stirling, D.; Quilliam, M.; Blackburn, S.; Bolch, C.; Burton, I.; Eaglesham, G.; Thomas, K.; Walter, J.; Willis, R. Three novel hydroxybenzoate saxitoxin analogues isolated from the dinoflagellate Gymnodinium catenatum. Chem. Res. Toxicol. 2003, 16, 1029-1033.

87. Sako, Y.; Kim, C.H.; Ishida, Y. Mendelian inheritance of paralytic shellfish poisoning toxin in the marine dinoflagellate Alexandrium. Biosci. Biotechnol. Biochem. 1992, 56692-56694.

88. Sako, Y.; Naya, N.; Yoshida, Y.; Kim, C.H.; Ushida, A.; Ishida, Y. Studies on the stability and heredity of PSP toxin composition in the toxic dinoflagellate Alexandrium. In Harmful Marine Algal Blooms; Lassus, P., Arzul, G., Erard, P., Gentien, C., Marcaillou-Le Baut, C., Eds.; London-Paris-New York: Nantes, France, 1995; pp. 345-350.

89. Velzeboer, R.M.A.; Baker, P.D.; Rositano, J.; Heresztyn, T.; Codd, G.A.; Raggett, S.L. Geographical patterns of occurrence and composition of saxitoxins in the cyanobacterial genus Anabaena (Nostocales, Cyanophyta) in Australia. Phycologia 2000, 39, 395-407.

90. Mahmood, N.A.; Carmichael, W.W. Paralytic shellfish poisons produced by the freshwater cyanobacterium Aphanizomenon flos-aquae NH-5. Toxicon 1986, 24, 175-186.

91. Harada, T.; Oshima, Y.; Yasumoto, T. Structure of two paralytic shellfish toxins, gonyautoxins V and VI, isolated from a tropical dinoflagellate Pyrodinium bahamense var. compressa. Agric. Biol. Chem. 1982, 46, 1861-1864.

92. Oshima, Y.; Hasegawa, M.; Yasumoto, T.; Hallegaeff, G.; Blackburn, S. Dinoflagellate Gimnodium catenatum as the source of paralytic shellfishtoxins in Tasmanian shellfish. Toxicon 1987, 25, 1105-1111. 
93. Shimizu, Y. Chemistry and Distribution of Deleterious Dinoflagellate Toxins; Faulkner, D., Fenical, W., Eds.; Plenum: New York, NY, USA, 1977; pp. 261-269.

94. Carmichael, W.W.; Evans, W.R.; Yin, Q.Q.; Bell, P.; Moczydlowski, E. Evidence for paralytic shellfish poisons in the freshwater cyanobacterium Lyngbya wollei (Farlow ex Gomont) comb. nov. Appl. Environ. Microbiol. 1997, 63, 3104-3110.

95. Humpage, A.R.; Rositano, J.; A., B.; Brown, R.; Baker, P.; Nicholson, B.C.; Steffensen, D.A. Paralytic shellfish poisons from australian cyanobacterial blooms. Aust. J. Mar. Freshwater Res. 1994, 45, 761-771.

96. Lagos, N.; Onodera, H.; Zagatto, P.A.; Andrinolo, D.; Azevedo, S.M.; Oshima, Y. The first evidence of paralytic shellfish toxins in the fresh water cyanobacterium Cylindrospermopsis raciborskii, isolated from Brazil. Toxicon 1999, 37, 1359-1373.

97. Ballot, A.; Fastner, J.; Wiedner, C. Paralytic shellfish poisoning toxin-producing cyanobacterium Aphanizomenon gracile in northeast Germany. Appl. Environ. Microbiol. 2010, 76, 1173-1180.

98. Llewellyn, L.E. Saxitoxin, a toxic marine natural product that targets a multitude of receptors. Nat. Prod. Rep. 2006, 23, 200-222.

99. Llewellyn, L.E.; Negri, A.P.; Doyle, J.; Baker, P.D.; Beltran, E.C.; Neilan, B.A. Radioreceptor assays for sensitive detection and quantitation of saxitoxin and its analogues from strains of the freshwater cyanobacterium, Anabaena circinalis. Environ. Sci. Technol. 2001, 35, 1445-1451.

100. Oshima, Y. Postcolumn derivatization liquid chromatographic method for paralytic shellfish toxins. J. AOAC Int. 1995, 78, 528-532.

101. Oshima, Y.; Blackburn, S.; Hallegraeff, G.M. Comparative study on paralytic shellfish toxin profiles of the dinoflagellate Gymnodinium catenatum from three different countries. Mar. Biol. 1993, 116, 471-476.

102. Onodera, H.; Satake, M.; Oshima, Y.; Yasumoto, T.; Carmichael, W.W. New saxitoxin analogues from the freshwater filamentous cyanobacterium Lyngbya wollei. Nat. Toxins 1997, 5, 146-151.

103. Arakawa, O.; Nishio, S.; Noguchi, T.; Shida, Y.; Onoue, Y. A new saxitoxin analogue from a xanthid crab Atergatis floridus. Toxicon 1995, 33, 1577-1584.

104. Arakawa, O.; Noguchi, T.; Shida, Y.; Onoue, Y. Occurrence of carbamoyl- $N$-hydroxy derivatives of saxitoxin and neosaxitoxin in a xanthid crab Zosimus aeneus. Toxicon 1994, 32, 175-183.

105. Zaman, L.; Arakawa, O.; Shimosu, A.; Shida, Y.; Onoue, Y. Occurrence of a methyl derivative of saxitoxin in Bangladeshi freshwater puffers. Toxicon 1998, 36, 627-630.

106. Yotsu-Yamashita, M.; Kim, Y.H.; Dudley, S.C. Jr., ; Choudhary, G.; Pfahnl, A.; Oshima, Y.; Daly, J.W. The structure of zetekitoxin AB, a saxitoxin analog from the golden frog Atelopus zeteki: a potent sodium channel blocker. Proc. Natl. Acad. Sci. USA 2004, 101, 4346-4351.

107. Kao, C.Y. Paralytic shellfish poisoning. In Algal Toxins in Seafood and Drinking Water; Falconer, I.R., Ed.; Academic Press: London, UK, 1993; pp. 75-86.

108. Kao, C.Y.; Levinson, S.R. Tetrodotoxin, Saxitoxin, and the Molecular Biology of the Sodium Channel; The New York Academy of Science: New York, NY, USA, 1986; Volume 479.

109. Su, Z.; Sheets, M.; Ishida, H.; Li, F.; Barry, W.H. Saxitoxin blocks L-type ICa. J. Pharmacol. Exp. Ther. 2004, 308, 324-329. 
110. Wang, J.; Salata, J.J.; Bennett, P.B. Saxitoxin is a gating modifier of HERG K+ channels. J. Gen. Physiol. 2003, 121, 583-598.

111. Halstead, B.W.; Schantz, E.J. Paralytic shellfish poisoning. WHO Offset Publ. 1984, 1-59.

112. Evans, M.H. Mechanism of saxitoxin and tetrodotoxin poisoning. Br. Med. Bull. 1969, 25, 263-267.

113. Satin, J.; Kyle, J.W.; Chen, M.; Bell, P.; Cribbs, L.L.; Fozzard, H.A.; Rogart, R.B. A mutant of TTX-resistant cardiac sodium channels with TTX-sensitive properties. Science 1992, 256, $1202-1205$.

114. Strichartz, G. Structural determinabts of the affinity of saxitoxin for neuronal sodium channels. $J$. Gen. Physiol. 1984, 84, 281-305.

115. Tikhonov, D.B.; Zhorov, B.S. Modeling P-loops domain of sodium channel: homology with potassium channels and interaction with ligands. Biophys. J. 2005, 88, 184-197.

116. Jiang, Y.; Lee, A.; Chen, J.; Cadene, M.; Chait, B.T.; MacKinnon, R. The open pore conformation of potassium channels. Nature 2002, 417, 523-526.

117. Hall, S.; Strichartz, G.; Moczydlowski, E.; Ravindran, A.; Reichardt, P.B. The saxitoxins: sources, chemistry and pharmacology. In Marine Toxins. Origin, Structure and Pharmacology; Hall, S., Reichardt, P.B., Eds.; American Chemical Society: Washington DC, USA, 1990; pp. 29-69.

118. Cembella, A.D.; Shumway, S.E.; Larocque, R. Sequestering and putative biotransformation of paralytic shellfish toxins by the sea scallop Placopecten magellanicus - seasonal and spatial scales in natural populations. J. Exp. Mar. Biol. Ecol. 1994, 180, 1-22.

119. Cembella, A.D.; Shumway, S.E.; Lewis, N.I. Anatomical distribution and spatiotemporal variation in paralytic shellfish toxin composition in two bivalve species from the Gulf of Maine. J. Shellfish Res. 1993, 12, 389-403.

120. Kellmann, R.; Mihali, T.K.; Jeon, Y.J.; Pickford, R.; Pomati, F.; Neilan, B.A. Biosynthetic intermediate analysis and functional homology reveal a saxitoxin gene cluster in cyanobacteria. Appl. Environ. Microbiol. 2008, 74, 4044-4053.

121. Neuwald, A.F.; Landsman, D. GCN5-related histone N-acetyltransferases belong to a diverse superfamily that includes the yeast SPT10 protein. Trends Biochem. Sci. 1997, 22, 154-155.

122. Hederstedt, L.; Rutberg, L. Succinate dehydrogenase--a comparative review. Microbiol. Rev. 1981, 45, 542-555.

123. Mahmood, N.A.; Carmichael, W.W. The pharmacology of anatoxin-a(s), a neurotoxin produced by the freshwater cyanobacterium Anabaena flos-aquae NRC 525-17. Toxicon 1986, 24, $425-434$.

124. Sako, Y.; Yoshida, T.; Uchida, A.; Arakawa, O.; Noguchi, T.; Ishida, Y. Purification and characterization of a sulfotransferase specific to N-21 of saxitoxin and gonyautoxin $2+3$ from the toxic dinoflagellate Gymnodinium catenatum (Dinophyceae). J. Phycol 2001, 37, 1044-1051.

125. Yoshida, T.; Sako, Y.; Uchida, A.; Kakutani, T.; Arakawa, O.; Noguchi, T.; Ishida, Y. Purification and characterization of sulfotransferase specific to O-22 of 11-hydroxy saxitoxin from the toxic dinoflagellate Gymnodinium catenatum (dinophyceae). Fish. Sci. 2002, 68, $634-642$. 
126. Schwedock, J.S.; Long, S.R. Rhizobium meliloti genes involved in sulfate activation: the two copies of nodPQ and a new locus, sua. Genetics 1992, 132, 899-909.

127. Akoh, C.C.; Lee, G.C.; Liaw, Y.C.; Huang, T.H.; Shaw, J.F. GDSL family of serine esterases/lipases. Prog. Lipid Res. 2004, 43, 534-552.

128. Pomati, F.; Rossetti, C.; Manarolla, G.; Burns, B.P.; Neilan, B.A. Interactions between intracellular $\mathrm{Na}+$ levels and saxitoxin production in Cylindrospermopsis raciborskii T3. Microbiology 2004, 150, 455-461.

129. Brown, M.H.; Paulsen, I.T.; Skurray, R.A. The multidrug efflux protein NorM is a prototype of a new family of transporters. Mol. Microbiol. 1999, 31, 394-395.

130. Anderson, D.M.; Kulis, D.M.; Sullivan, J.J.; Hall, S.; Lee, C. Dynamics and physiology of saxitoxin production by the dinoflagellates Alexandrium spp. Mar. Biol. 1990, 104, 511-524.

131. Dias, E.; Pereira, P.; Franca, S. Production of paralytic shellfish toxins by Aphanizomenon sp. LMECYA 31 (cyanobacteria). J. Phycol. 2002, 38, 705-712.

132. Gedaria, A.I.; Luckas, B.; Reinhardt, K.; Azanza, R.V. Growth response and toxin concentration of cultured Pyrodinium bahamense var. compressum to varying salinity and temperature conditions. Toxicon 2007, 50, 518-529.

133. Steed, P.M.; Wanner, B.L. Use of the rep technique for allele replacement to construct mutants with deletions of the pstSCAB-phoU operon: evidence of a new role for the PhoU protein in the phosphate regulon. J. Bacteriol. 1993, 175, 6797-6809.

134. Ehria, S.; Ohmori, M. NrrA, a nitrogen-responsive response regulator facilitates heterocyst development in the cyanobacterium Anabaena sp. strain PCC 7120. Mol. Microbiol. 2006, 59, 1692-1703.

135. Forst, S.; Delgado, J.; Inouye, M. Phosphorylation of OmpR by the Osmosensor EnvZ Modulates Expression of the ompF and ompC Genes in Escherichia coli. Proc. Natl. Acad. Sci. USA 1989, 86, 6052-6056.

136. Mihali, T.K.; Kellmann, R.; Neilan, B.A. Characterisation of the paralytic shellfish toxin biosynthesis gene clusters in Anabaena circinalis AWQC131C and Aphanizomenon sp. NH-5. BMC Biochem. 2009, 10, 8.

137. Kellmann, R.; Mihali, T.K.; Neilan, B.A. Identification of a saxitoxin biosynthesis gene with a history of frequent horizontal gene transfers. J. Mol. Evol. 2008, 67, 526-538.

138. Bourke, A.T.C.; Hawes, R.B.; Neilson, A.; Stallman, N.D. An outbreak of hepato-enteritis (the Palm Island mystery disease) possibly caused by algal intoxication. Toxicon 1983, 21, 45-48.

139. Byth, S. Palm Island mystery disease. Med. J. Aust. 1980, 2, 40-42.

140. Saker, M.L.; Thomas, A.D.; Norton, J.H. Cattle mortality attributed to the toxic cyanobacterium Cylindrospermopsis raciborskii in an outback region of North Queensland. Environ. Toxicol. Water Qual. 1999, 14, 179-182.

141. Banker, R.; Carmeli, S.; Hadas, O.; Teltsch, B.; Porat, R.; Sukenik, A. Identification of cylindrospermopsin in Aphanizomenon ovalisporum (Cyanophyceae) isolated from Lake Kinneret, Israel. J. Phycol. 1997, 33, 613-616.

142. Harada, K.-I.; Ohtani, I.; Iwamoto, K.; Suzuki, M.; Watanabe, M.F.; Watanabe, M.; Terao, K. Isolation of cylindrospermopsin from a cyanobacterium Umezakia natans and its screening method. Toxicon 1994, 32, 73-84. 
143. Li, R.; Carmichael, W.W.; Brittain, S.; Eaglesham, G.K.; Shaw, G.R.; Liu, Y.; Watanabe, M.M. First report of the cyanotoxins cylindrospermopsin and deoxycylindrospermopsin from Raphidiopsis curvata (Cyanobacteria). J. Phycol. 2001, 37, 1121-1126.

144. Li, R.; Carmichael, W.W.; Brittain, S.; Eaglesham, G.K.; Shaw, G.R.; Mahakhant, A.; Noparatnaraporn, N.; Yongmanitchai, W.; Kaya, K.; Watanabe, M.M. Isolation and identification of the cyanotoxin cylindrospermopsin and deoxy-cylindrospermopsin from a Thailand strain of Cylindrospermopsis raciborskii (Cyanobacteria). Toxicon 2001, 39, 973-980.

145. Preussel, K.; Stuken, A.; Wiedner, C.; Chorus, I.; Fastner, J. First report on cylindrospermopsin producing Aphanizomenon flos-aquae (Cyanobacteria) isolated from two German lakes. Toxicon 2006, 47, 156-162.

146. Schembri, M.A.; Neilan, B.A.; Saint, C.P. Identification of genes implicated in toxin production in the cyanobacterium Cylindrospermopsis raciborskii. Environ. Toxicol. 2001, 16, 413-421.

147. Spoof, L.; Berg, K.A.; Rapala, J.; Lahti, K.; Lepisto, L.; Metcalf, J.S.; Codd, G.A.; Meriluoto, J. First observation of cylindrospermopsin in Anabaena lapponica isolated from the boreal environment (Finland). Environ. Toxicol. 2006, 21, 552-560.

148. Seifert, M.; McGregor, G.; Eaglesham, G.; Wickramasinghe, W.; Shaw, G. First evidence for the production of cylindrospermopsin and deoxy-cylindrospermopsin by the freshwater benthic cyanobacterium, Lyngbya wollei (Farlow ex Gomont) Speziale and Dyck. Harmful Algae 2007, 6, 73-80.

149. Neilan, B.A.; Saker, M.L.; Fastner, J.; Torokne, A.; Burns, B.P. Phylogeography of the invasive cyanobacterium Cylindrospermopsis raciborskii. Mol. Ecol. 2003, 12, 133-140.

150. Ohtani, I.; Moore, R.E.; Runnegar, M.T.C. Cylindrospermopsin: A potent hepatotoxin from the blue-green alga Cylindrospermopsis raciborskii. J. Am. Chem. Soc. 1992, 114, 7941-7942.

151. Banker, R.; Carmeli, S.; Werman, M.; Teltsch, B.; Porat, R.; Sukenik, A. Uracil Moiety is Required for Toxicity of the Cyanobacterial Hepatotoxin Cylindrospermopsin. J. Toxicol. Environ. Health Part A 2001, 62, 281-288.

152. Runnegar, M.T.; Kong, S.M.; Zhong, Y.Z.; Lu, S.C. Inhibition of reduced glutathione synthesis by cyanobacterial alkaloid cylindrospermopsin in cultured rat hepatocytes. Biochem. Pharmacol. 1995, 49, 219-225.

153. Runnegar, M.T.; Kong, S.M.; Zhong, Y.Z.; Ge, J.L.; Lu, S.C. The role of glutathione in the toxicity of a novel cyanobacterial alkaloid cylindrospermopsin in cultured rat hepatocytes. Biochem. Biophys. Res. Commun. 1994, 201, 235-241.

154. Runnegar, M.T.; Xie, C.; Snider, B.B.; Wallace, G.A.; Weinreb, S.M.; Kuhlenkamp, J. In vitro Hepatotoxicity of the Cyanobacterial Alkaloid Cylindrospermopsin and Related Synthetic Analogues. Toxicol. Sci. 2002, 67, 81-87.

155. Kiss, T.; Vehovszky, A.; Hiripi, L.; Kovacs, A.; Voros, L. Membrane effects of toxins isolated from a cyanobacterium, Cylindrospermopsis raciborskii, on identified molluscan neurones. Comp. Biochem. Physiol. C: Toxicol. Pharmacol. 2002, 131, 167-176.

156. Humpage, A.R.; Fenech, M.; Thomas, P.; Falconer, I.R. Micronucleus induction and chromosome loss in transformed human white cells indicate clastogenic and aneugenic action of the cyanobacterial toxin, cylindrospermopsin. Mutat. Res. 2000, 472, 155-161. 
157. Froscio, S.M.; Humpage, A.R.; Burcham, P.C.; Falconer, I.R. Cylindrospermopsin-induced protein synthesis inhibition and its dissociation from acute toxicity in mouse hepatocytes. Environ. Toxicol. Water Qual. 2003, 18, 243-251.

158. Norris, R.L.; Eaglesham, G.K.; Pierens, P.; Shaw, G.R.; Smith, M.J.; Chiswell, R.K.; Seawright, A.A.; Moore, M.R. Deoxycylindrospermopsin, an analog of cylindrospermopsin from Cylindrospermopsis raciborskii. Environ. Toxicol. Water Qual. 1999, 14, 163-165.

159. Terao, K.; Ohmori, S.; Igarashi, K.; Ohtani, I.; Watanabe, M.F.; Harada, K.I.; Ito, E.; Watanabe, M. Electron microscopic studies on experimental poisoning in mice induced by cylindrospermopsin isolated from blue-green alga Umezakia natans. Toxicon 1994, 32, 833-843.

160. Wiegand, C.; Pflugmacher, S. Ecotoxicological effects of selected cyanobacterial secondary metabolites: a short review. Toxicol. Appl. Pharmacol. 2005, 203, 201-218.

161. Mihali, T.K.; Kellmann, R.; Muenchhoff, J.; Barrow, K.D.; Neilan, B.A. Characterization of the gene cluster responsible for cylindrospermopsin biosynthesis. Appl. Environ. Microbiol. 2008, 74, 716-722.

162. Burgoyne, D.L.; Hemscheidt, T.K.; Moore, R.E.; Runnegar, M.T. Biosynthesis of cylindrospermopsin. J. Org. Chem. 2000, 65, 152-156.

163. Kellmann, R.; Mills, T.; Neilan, B.A. Functional modeling and phylogenetic distribution of putative cylindrospermopsin biosynthesis enzymes. J. Mol. Evol. 2006, 62, 267-280.

164. Shalev-Alon, G.; Sukenik, A.; Livnah, O.; Schwarz, R.; Kaplan, A. A novel gene encoding amidinotransferase in the cylindrospermopsin producing cyanobacterium Aphanizomenon ovalisporum. FEMS Microbiol. Lett. 2002, 209, 87-91.

165. Baldwin, J.E.; Thomas, R.C.; Kruse, L.I.; Silberman, L. Rules for ring closure: ring formation by conjugate addition of oxygen nucleophiles. J. Org. Chem. 1977, 42, 3846-3852.

166. Norris, R.L.; Seawright, A.A.; Shaw, G.R.; Senogles, P.; Eaglesham, G.K.; Smith, M.J.; Chiswell, R.K.; Moore, M.R. Hepatic xenobiotic metabolism of cylindrospermopsin in vivo in the mouse. Toxicon 2002, 40, 471-476.

167. Saker, M.L.; Neilan, B.A.; Griffiths, D.J. Two morphological forms of cylindrospermopsis raciborskii (cyanobacteria) isolated from Solomon dam, palm island, Queensland. J. Phycol. 1999, 35, 599-606.

168. Hansel, A.; Axelsson, R.; Lindberg, P.; Troshina, O.Y.; Wunschiers, R.; Lindblad, P. Cloning and characterisation of a hyp gene cluster in the filamentous cyanobacterium Nostoc sp. strain PCC 73102. FEMS Microbiol. Lett. 2001, 201, 59-64.

169. Tamagnini, P.; Axelsson, R.; Lindberg, P.; Oxelfelt, F.; Wünschiers, R.; Lindblad, P. Hydrogenases and Hydrogen Metabolism of Cyanobacteria. Microbiol. Mol. Biol. Rev. 2002, 66, $1-20$.

(C) 2010 by the authors; licensee MDPI, Basel, Switzerland. This article is an open-access article distributed under the terms and conditions of the Creative Commons Attribution license (http://creativecommons.org/licenses/by/3.0/). 